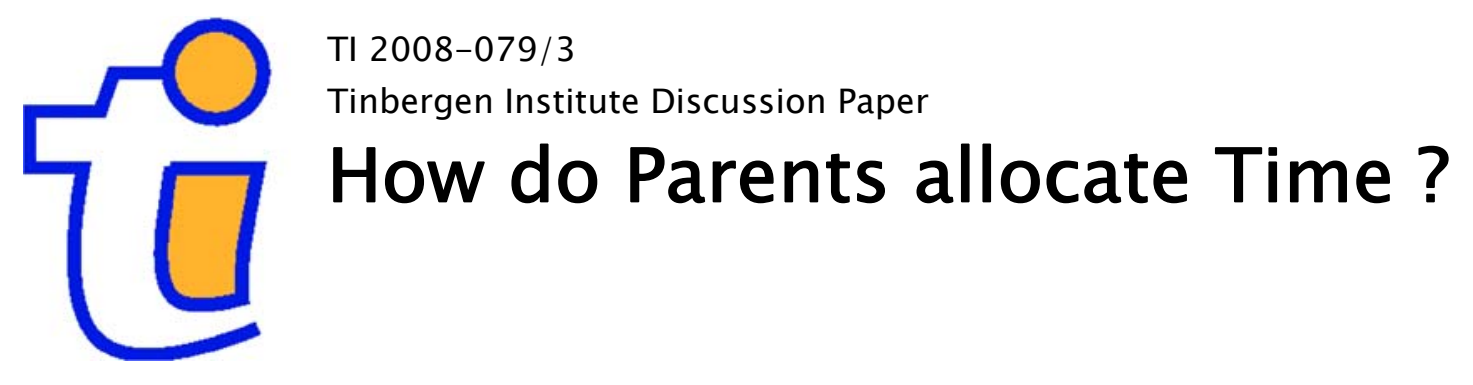

Hans G. Bloemen'

Elena G.F. Stancanelli2

' Department of Economics, Free University Amsterdam, Tinbergen Institute, IZA, and Netspar; 2 CNRS, THEMA, University of Cergy Pontoise. 


\section{Tinbergen Institute}

The Tinbergen Institute is the institute for economic research of the Erasmus Universiteit Rotterdam, Universiteit van Amsterdam, and Vrije Universiteit Amsterdam.

Tinbergen Institute Amsterdam

Roetersstraat 31

1018 WB Amsterdam

The Netherlands

Tel.: +31(0)205513500

Fax: $+31(0) 205513555$

Tinbergen Institute Rotterdam

Burg. Oudlaan 50

3062 PA Rotterdam

The Netherlands

Tel.: + $31(0) 104088900$

Fax: $+31(0) 104089031$

Most TI discussion papers can be downloaded at http://www.tinbergen.nl. 


\title{
How do parents allocate time : the effects of wages and income
}

\author{
Hans G. Bloemen* and Elena G. F. Stancanelli**
}

September $2008^{* * *}$

Keywords: time use, work behaviour, household economics.

Classification JEL: D1, D13, J21

\begin{abstract}
This paper focuses on the time allocation of spouses and the impact of economic variables. We present a stylized model of the time allocation of spouses to illustrate the expected impact of wages and non-labour income. The empirical model simultaneously specifies three time-use choices -paid work, childcare, and housework- and wage and employment equations for each spouse, allowing for correlation across the errors of the ten equations. We exploit the rich information in the French time-use survey 1998-99 to estimate the model. The predictions of the theoretical model are mostly validated with the main exception of the standard hypothesis that performing housework does not bring utility. Parents' market time responds positively to changes in own wage. The own-wage elasticity of housework is negative while childcare does not react to changes in own wage. Women's non-market time is independent of their husband's wage; but both housework and childcare of fathers react positively to an increase in their wife's wage. Nonlabour income reduces paid work by parents and increases their non-market time. Higher-educated and older parents spend more time with their children. There are significant and positive correlations across the errors of the spousal equations.
\end{abstract}

* Free University Amsterdam, Department of Economics, De Boelelaan 1105, 1081 HV Amsterdam, The Netherlands, Tinbergen Institute, IZA, and Netspar.

** CNRS, THEMA, University of Cergy Pontoise

*** This research has benefited from a grant by the French National Research Agency (ANR). The data for this paper were made available by the INSEE. We thank the participants to a workshop on the labour market behaviour of couples that we organized in Nice in June 2008 for their comments. All errors are ours. 


\section{Introduction}

This paper studies the time allocation of spouses in two-parent households and the impact of economic incentives. Conventional economic models of household behaviour ignore non-market activities, implicitly assuming that they are equivalent to pure leisure time. Pioneering work in this area, introducing the concept of household production and the choice of time allocation is due to Becker $(1965,1981)$ and Gronau (1976). Kooreman and Kapteyn (1987) present a structural model of time allocation of couples disaggregating non-market work into many separate categories, like, notably, childcare. More recently, Apps and Rees (1996, 1997 and 2002) introduce household production in a collective household model, arguing that non-market activities are clearly distinct from leisure; and Apps (2003) points out that implicitly setting non-market work equal to 'leisure' likely biases conventional labour-supply elasticities. Chiappori (1997) allows for home production in the collective model of household behaviour.

The empirical literature on the time allocation decisions of spouses within the same household and the impact of economic incentives is still scarse, especially as many timeuse surveys do not collect any information on wages and income. Some exceptions are Kalenkoski, Ribar and Stratton (2008), who estimate the impact of wages on the childcare time of British parents, concluding that while women's time allocation to paid work and childcare responds to own and cross (spouse's) wage, that of men is not responsive to own wage. Connelly and Kimmel (2007) investigate spousal leisure, home production and childcare and the impact of wages for American households, making special assumptions to get round the fact that in the American Time Use Survey the time-diary was collected for only one respondent in each household. Hersch and Stratton (1994) use a global time-use question from the Michigan Panel Study of Income Dynamics to investigate the relationship between spouses' housework and wages, finding evidence of a vicious circle of wages and housework for women: they do more housework because their wage is lower than their husbands, and doing housework lowers their wage further. All of the earlier studies allow wages to affect spousal time allocation by instrumenting or predicting wages, to our knowledge. In this paper, instead, we model simultaneously the 
wage rates, the employment, and the time allocation of spouses.

We here set up a stylized theoretical model of parents' utility maximization that enables us to determine the theoretical predictions concerning the wage and income responses of spouses' supply of market and non-market time. This issue is particularly relevant for policy purposes as wages and non-labour income can be affected by policy measures like minimum wages, income taxation and various types of governement subsidies. We separate non-market work into leisure time, childcare and housework. This latter includes activities such as shopping, cleaning, doing the laundry, washing up the dishes, doing paperwork and going to administrative offices. The utility individuals derive from performing these activities is likely to differ to that from caring for their children. We assume, as conventional in most of the literature in this area, that spouses derive no utility from performing housework: an assumption which is actually rejected according to the estimation results. On the contrary, parents are expected to value the time they spend caring for their children. Further to this, parental time with children is likely to add to the children's human capital, producing thus extra rewards for caring parents.

The empirical model is sufficiently general that we can test for the validity of the theoretical model's predictions. We allow simultaneously for a three-fold time use choice of spouses within each household; wage and employment equations for each spouse are also estimated simultaneously, allowing for correlations between the errors of the ten equations. This allow us to test for the impact of own and cross wage rates, as well as for non-labour income effects, on spousal time allocation decisions. In addition to this, we investigate how wages and non-labour income affect the total time spent at the household level (by the two spouses in each household) on a given activity -which is quite new in the literature, to our knowledge.

We also allow for possible correlation of the unobservable components of the time allocation choices of the parents. Correlations in unobservables may capture factors like positive assortative mating and/or polarization of spouses' behaviour due to unobservable characteristics. For example, individuals may marry others who have similar (unobservable) characteristics -reflecting positive assortative mating- or both parents 
may like to work longer hours in market work -in line with the polarization of long hours of work at the household level, and contrary to the 'specialization' of one spouse in market work and the other in housework. Further to this, if unobservable components of the time allocated to caring for children by parents are positively correlated, then some couples will spend increasingly more time on children than others. Since time spent with children by parents very likely adds to the children's human capital, this may increase overall inequality, especially if it is the higher educated that spend more time on childcare -which is what we actually find, in line with the applied literature in this area.

This model is substantially more general than earlier empirical studies in this area. We use information on market wages and household non-labour income, which is also new in the empirical literature, since few time-use datasets contain all of these variables as well as collecting diary information on both spouses' time choices. We exploit the richness of information collected by the French time-use survey 1998-99 to estimate the model. This has the advantage of including individual earnings, usual hours of work and total household income, in addition to diary information on how household members allocate their time to different activities. The time diary was collected for all individuals in the household, so we have time-use information for both spouses in the couple.

The predictions of the theoretical model are mostly validated in the empirical estimation with the main exception of the standard hypothesis that performing housework does not bring utility. Parents' market time responds positively to changes in own wage, as expected, but not to cross-wages. The cross-wage elasticities of market time are negative, as predicted by the theory, but not significant. The own-wage elasticity of housework of fathers is negative, as expected, and the cross-wage elasticity is statistically significant and positive. Housework of women falls as their wage increases, in line with the theoretical predictions, and it does not depend on the husband's wage. Childcare time of mothers is not sensitive to wage incentives. Instead, an increase in the mother's wage results in more childcare time and housework of fathers. Non-labour income reduces the time allocated to paid work and increases spouses' housework and childcare time. We find significant and positive correlations across the errors of the two spouses' childcare equations, within each household. The estimation results indicate also that higher 
educated and older parents spend more time with their children. Finally, we find that women's housework rises significantly with formal marriage.

According to international comparisons (OECD, 2001), French husbands perform less of non-market activities than men in many other OECD countries. On the other hand, participation rates in market and non-market work of French women are more or less in line with those in most other OECD countries. It is hard to say a priori whether our estimates can be generalized to other countries, as, moreover, the results are conditional on the quality of the specific data to hand. It is also difficult to compare our estimated elasticites to those from earlier studies that adopted a different methodology, since they were also based on different countries.

The structure of the paper is as follows. The next section describes the theoretical setup. The empirical model is specified next, and the data are described. In the following sections, we provide some descriptive statistics and comment on the model-estimation results. The last section concludes the paper.

\section{A theoretical framework of time allocation within the household}

\section{$2.1 \quad$ The basic model}

We write down a stylized model for the allocation of spouses' time, distinguishing between the time allocated to paid work, housework, childcare, and 'pure' leisure. Let us use the following notation, with $k=m$ for husbands, and $f$ for wives: 
$C_{k} \quad$ private consumption of household member $k$

$C_{h h} \quad$ (public) consumption of goods produced with housework time

$C_{c h}$ (public) consumption of goods produced with childcare time

$C_{h m}$ housework services bought from the market

$C_{c m}$ childcare services bought from the market

$t_{1 k} \quad$ time spent on paid work by household member $k$

$t_{2 k} \quad$ time spent on housework by household member $k$

$t_{3 k} \quad$ time spent on children by household member $k$

$l_{k} \quad$ leisure time of household member $k$

$w_{k} \quad$ hourly wage rate of household member $k$

$p_{h} \quad$ market price of housework services

$p_{c} \quad$ market price of childcare services

$\mu$ household non-labour income

We assume that each household member has private consumption $C_{k}$, but that housework and childcare services are public goods for the household. The total consumption of housework $C_{h}$ consists of services $C_{h h}$, produced with household time inputs, and services bought from the market $C_{h m}:^{1}$

$$
C_{h}=C_{h m}+C_{h h}
$$

Similarly, we write household consumption of child care as:

$$
C_{c}=C_{c m}+C_{c h}
$$

Home-produced housework $C_{h h}$ can be expressed as the output of a production function, $g_{h}$, with time inputs, $t_{2 k}:^{2}$

$$
C_{h h}=g_{h}\left(t_{2 m}, t_{2 f}\right)
$$

The household childcare production function $\left(C_{c h}\right)$ is then:

$$
C_{c h}=g_{c}\left(t_{3 m}, t_{3 f}\right)
$$

\footnotetext{
${ }^{1}$ Note that Equation 1 assumes that housework services produced at home or bought in the market are perfect substitutes. This assumption can easily be relaxed, for instance by writing $C_{h}=C_{h m}+$ $\theta C_{h h}$, where $\theta$ is a preference parameter. To generalize further, we may include $C_{h m}$ and $C_{h h}$ as separate arguments in the utility function, thereby allowing them to be imperfect substitutes or even complements. The same remarks apply to Equation 2.

${ }^{2}$ We apply the regularity condition that the marginal productivity of the time inputs is positive and decreasing, as in Gronau (1976). The time inputs represent the household production technology. We do not allow for more variation in marginal productivities of household production (see Apps, 2003, for a discussion).
} 
Household members derive utility from private consumption and public consumption of housework and childcare. In addition, their utility is influenced by the time they spend on children, and their 'pure' leisure time:

$$
U_{k}\left(C_{k}, C_{h}, C_{c}, t_{3 k}, l_{k}\right), k=m, f
$$

As is usual, we assume that utility is increasing in all of its arguments. By including time allocated to caring for children in the utility function, we explicitly allow for the possibility that parents derive utility from the time spent on this activity, in addition to the services $C_{c h}$ derived from this activity (see Equations 2 and 4). We do not explicitly include the time spent on housework in the utility function, as we assume that spouses derive no direct utility from this activity but only from the services generated by it, $C_{h h \cdot} \cdot^{3}$

The total time endowment (say 24 hours) of each household member $k$ is $T$ and the time constraint is:

$$
T=\sum_{l=1}^{3} t_{l k}+l_{k}, k=m, f
$$

Given the wage rate, $w_{j}$, and household non-labour income, $\mu$, the household budget constraint is:

$$
C_{m}+C_{f}+p_{h} C_{h m}+p_{c} C_{c m}=w_{m} t_{1 m}+w_{f} t_{1 f}+\mu
$$

The household welfare function, $V($.$) , can be seen as a weighted average of the indi-$ vidual utility function for each household member:

$$
\begin{aligned}
& V\left(C_{m}, C_{f}, C_{h}, C_{c}, t_{3 m}, t_{3 f}, l_{m}, l_{f}\right)= \\
& \quad=\lambda U_{m}\left(C_{m}, C_{h}, C_{c}, t_{3 m}, l_{m}\right)+(1-\lambda) U_{f}\left(C_{f}, C_{h}, C_{c}, t_{3 f}, l_{f}\right)
\end{aligned}
$$

The value of $\lambda$ represents the bargaining power of one spouse relative to the other. In the collective model, the weight $\lambda$ depends on the husband's and wife's wage rates, and on the household's non-labour income. ${ }^{4}$

\footnotetext{
3 The time spent on housework thus enters the model in the same way as paid work in the conventional labour supply model.

${ }^{4}$ In addition, $\lambda$ may depend on 'distribution factors' that affect bargaining power but not individual utility. Pollak (2005) shows how wage rates affect bargaining power of spouses in a model that incorporates household production.
} 
The objective of the household is to maximize household welfare (8) subject to the constraints (1), (2), (3), (4), (6), and (7). Solving the model (see Appendix A) provides us with the spouses' optimal time-choice equations:

$$
t_{j k}^{*}=t_{j k}\left(w_{m}, w_{f}, \mu, p_{h}, p_{c}\right), k=m, f ; j=1,2,3
$$

The demand functions for housework time and child care services bought from the market are then:

$$
\begin{aligned}
& C_{h m}^{*}=C_{h m}\left(w_{m}, w_{f}, \mu, p_{h}, p_{c}\right) \\
& C_{c m}^{*}=C_{c m}\left(w_{m}, w_{f}, \mu, p_{h}, p_{c}\right)
\end{aligned}
$$

These are not observed. ${ }^{5}$ This basic model does not allow for dynamics or intertemporal maximization. We also do not model time inputs of adults other than the parents, such as grandparents or the children themselves, which may contribute to household production.

\subsection{The effect of wages and income on the time allocation of spouses}

Table 1 summarizes the expected effects of wages and (non-labour) income on parents' time-allocation choices. We have split these effects up into 'substitution' and 'income' effects (see Appendix A for more details). We start by discussing the effect of an increase in the husband's wage rate $w_{m}$ on the time spent on housework. This latter can be solved separately from the rest of the model: the amount of time allocated to housework by each parent $k$ is such that its marginal productivity is equal to the ratio of the wage of spouse $k$ to the market price of housework services (see Equation 23 in Appendix A).

Under the assumption of positive and decreasing marginal productivity of housework done by parents, the husband will spend less time on housework as his own wage rises. The cross-wage effect on the wife's housework depends on the production technology (Equation 3). If husband's and wife's time spent on housework are complements in production, then the wife's time may also fall. If, instead, they are substitutes, the time she spends on housework will increase. If they are unrelated, because, for example, she specializes in household production, then her time is unaffected. The income effect of

\footnotetext{
${ }^{5}$ In the econometric specification, we allow for cross correlations in the unobservables of the time-use equations, which may partly capture omitted heterogeneity in market prices across households.
} 
a wage increase on time spent on housework is zero. ${ }^{6}$ The income effect will increase the consumption of housework services $C_{c}$, but this increase comes from an increase in housework services bought from the market. The substitution effect will increase the opportunity cost of the husband's non-market time and reduce that of his spouse. The substitution effect is thus negative for the husband's non-market activities, and positive for the wife's non-market activities. This is equivalent to saying that paid work time will increase for the husband and decrease for the wife.

Childcare time enters both the production function of child services and the utility function. The conventional substitution effect is negative, because child-care time for the husband becomes more expensive relative to the wife's. Thus, the husband will spend less time on childcare and the wife more. The effect that runs through the production function is also negative for the husband. For the wife, it depends on whether husband's and wife's time in childcare production are complements or substitutes (see above). The income effect will increase 'pure' leisure time and the time spent on children, provided that children are normal goods.

The total expected effects of wages and income on time allocation are shown in the lower part of Table 1. Theory unambiguously predicts negative effects of husband's wages on paid work of the wife and housework time of the husband. There are opposing income and substitution effects for the husband's paid work and time he spends caring for his children. The effects of husband's wages on the time that the wife spends on housework and childcare are not unambiguously signed from theory.

The effects of an increase in the wage rate of the wife mirror those for her husband, since there is no a priori gender specialization in the model.

An increase in non-labour income is equivalent to the income effects already discussed. The model predicts unambiguous effects of non-labour income on time-allocation choices: paid work will fall, and childcare time will rise. The zero effect for housework time results from the assumption that housework time does not enter the utility function explicitly, and that housework services bought from the market and produced at home are perfect

\footnotetext{
${ }^{6}$ This can easily be seen by noting that the solution of Equation 23 is independent of non-labour income.
} 
substitutes.

\section{The empirical model}

The econometric model is sufficiently general that we can test for the validity of the predictions of the theoretical model summarized in Table 1. No specific assumptions from the theoretical model (as, for instance, a zero income effect for housework) are imposed on the structure of the empirical model. The estimation of a structural model is not feasible since we have insufficient information on the market quantities and prices of housework and childcare.

We simultaneously model three time-allocation decisions -market work, household work and childcare- together with wages and employment of both parents. The model allows for corner solutions, as well as for continuous time decisions. This model is substantially more general than earlier empirical studies in this area.

We use information on market wages and household non-labour income, which is also new in the empirical literature, since few time-use datasets contain all of these variables as well as collecting diary information on both spouses' time choices.

Let $t_{i j k}$ denote the time spent on activity $j(j=1, \ldots, 3)$ by household member $k(k=$ $m, f)$ of household $i(i=1, \ldots, N)$. The time spent on any given activity depends on the wage rates $w_{i m}$ and $w_{i f}$ of the husband and wife, household non-labour income $\mu_{i}$, observed characteristics $x_{i k}$, and an error term $\epsilon_{i j k}$ :

$$
\begin{aligned}
& t_{i j k}^{*}=\alpha_{j k}^{m} \ln w_{i m}+\alpha_{j k}^{f} \ln w_{i f}+\psi_{j k} \mu_{i}+x_{i k}^{\prime} \beta_{j k}+\epsilon_{i j k} \\
& t_{i j k}=t_{i j k}^{*} \text { if } t_{i j k}^{*}>0 \\
& t_{i j k}=0 \text { otherwise } i=1, \ldots, N, j=1, \ldots, 3, k=m, f
\end{aligned}
$$

This system of equations allows zero time to be spent on a given activity. Individuals may spend no time on not only market employment, but also housework and childcare (see Section 4).

We then specify the following wage equations:

$$
\ln w_{i k}=z_{i k}^{\prime} \eta+u_{i k}, i=1, \ldots, N, k=m, f
$$


Since the wage rates in Equation 11 may be correlated with the error terms $\epsilon_{i j k}$ due to selection on unobservables -which may affect both wages and the time-allocation choices of spouses- we allow for non-zero correlations between the error terms in the time-use and the wage equations. Since wages are only observed for people who are formally employed, we assign wages to non-employed spouses by specifying the joint density function for time use and wages, and then integrating over wage rates for spouses for whom wages were not observed, when writing down the likelihood function to be maximized (see the Appendix).

Estimating Equations 11 and 12 simultaneously and allowing for correlation in the error terms may be insufficient to correct for the selectivity of wages on the basis of employment status. Wages are based on reported continuous earnings and usual hours of work from the individual questionnaire, while paid work time is measured here using the diary information, like for housework and childcare time. ${ }^{7}$ Thus, we estimate simultaneously an equation for the employment status of each spouse, based on their answer to a standard question on labour market status from the individual questionnaire. This also allows us to control for demand-side factors, by using the regional unemployment rate. We define employment as $e_{i k}$, with $e_{i k}=1$ if spouse $k$ of household $i$ is employed, and zero otherwise.

$$
\begin{aligned}
& e_{i k}^{*}=q_{i k}^{\prime} \gamma_{k}+\nu_{i k} \\
& e_{i k}=1 \text { if } e_{i k}^{*}>0 \\
& e_{i k}=0 \text { otherwise }
\end{aligned}
$$

Finally, we allow the errors of the employment equation (Equation 13) to be correlated with the errors of the time-use equations (Equation 11) and the wage equations (Equation 12), by defining:

$$
\omega_{i}=\left(\epsilon_{i m}^{\prime}, \epsilon_{i f}^{\prime}, \nu_{i m}, \nu_{i f}, u_{i m}, u_{i f}\right)^{\prime}
$$

7 It was the interviewer who established the day of the week on which the time diary was to be answered. We exclude from the analysis sample observations where the diary was filled in on special days, like a vacation, sickness leave day, wedding, etc. We also analyze separately couples who answered the diary during a week day, excluding those that answered the diary over weekend days. For consistency with the analysis of the time allocated to childcare and housework, which is only collected via the time diary, we also use information on market hours reported in the diary. See the next section for more details. 
We assume that:

$$
\omega_{i} \sim N(0, \Sigma)
$$

where $\Sigma$ is the unrestricted variance-covariance matrix of dimension $10 \times 10$ of the errors of this equation system. By letting the covariance matrix $\Sigma$ be unrestricted and estimating all of its elements, we allow for the simultaneity of spouses' time-allocation choices and wages. Correlation in unobservables between the time-use equations may arise from unobserved household-specific correlations in preferences (i.e. unobserved positive assortative matching effects), or productivity (someone who is productive in the labour market may also be productive in housework, or the opposite, if labour market attachment prevents individuals from accumulating housework experience), and, following the theoretical model, household-specific heterogeneity in market prices for housework and child care services.

The complete model now consists of six time-use equations (Equation 11), two employment equations (Equation 13), two wage equations (Equation 12) and the joint density (Equation 15) of the errors. We can then construct the likelihood contribution for each type of observation. To deal with the multidimensionality of the model, we employ simulated maximum-likelihood estimation (see Appendix B for details of this procedure).

\section{The French time-use data}

The data for the analysis are drawn from the 1998-99 French time-use survey (Enquête Emploi du temps), carried out by the National Statistical Office (INSEE).

This survey covers about 8000 representative households, and includes over 20,000 individuals of all ages from 0 to 103 years. Three questionnaires were collected: a household questionnaire, an individual questionnaire and the time diary. The diary was collected for all individuals in the household, which is an advantage over many other surveys that only have information on one randomly drawn individual in each household. The diary was filled in for one day, which was chosen by the interviewer and could be either a week or a weekend day. Another advantage of this dataset is that it 
collects information on household income, individual earnings, and usual hours of work in addition to the diary.

For our analysis, we select only two-parent households: lone parents were dropped from the sample. We selected married or cohabiting spouses according to the following criteria:

- the couple was heterosexual;

- both spouses were under 60 -this being the retirement age in France in 1998-99;

- both spouses had filled in the time diary;

- neither spouse had filled in the time diary on an 'exceptional day', defined as a special occasion such as a vacation day, a marriage or a party etc;

- neither spouse was self-employed; and

- the number of children (aged 18 or under) was positive;

Dropping single people made the sample size to shrink from 8186 to 5287 households while eliminating older couples reduced it from 5287 to 3819 households. There was only one homosexual couple, which we deleted. Next, we dropped 245 couples where either the husband or the wife had not filled the diary and 295 that had filled in the diary on an exceptional day. Applying the last two conditions above, produced a sample of 1473 two-parent couples, including spouses who answered the diary question at the weekend. Excluding this latter group, gives a sample of 1080 two-parent couples.

The age of children was constructed using the individual file information on the age of the children: everyone in the household was asked to complete the individual questionnaire. Education dummies are increasing in education level, with the omitted category being individuals without any formal educational qualifications. Regional dummies were included in the data using the regional unemployment rate for 1998, according to the BIT definition. These unemployment rates vary considerably across regions, from $7 \%$ in Alsace to $17 \%$ in Languedoc-Roussillon. The unemployment rate in the region of Paris (Ile-de-France), was just over $10 \%$. 
All earnings and income information in the survey was collected in French Francs (equal to 1/6.55957 Euros). Information on monthly gross earnings was collected both as a continuous variable and in intervals, for respondents who did not provide continuous earnings information. For them, we set earnings equal to the mid-point of each interval, and to the lower bound of the top interval. However, to construct the hourly wage rate, we consider only observations providing information on continous wages (roughly half of those who reported earnings). This produced hourly wages for 797 men and 533 women, of whom 577 men and 371 women did not answer the diary at the weekend.

Total household income before taxes was collected, though only in intervals. We set total household income (measured on a monthly basis) equal to the mid-point of each interval and equal to the lower bound of that interval for individuals in the top bracket. The resulting total household income figure was compared to the sum of the spouses' work earnings. If total household income was less than spouses' total earnings, it was set equal to the latter: this occurred in very few cases. Non-labour income was then set equal to the difference between total household income and total household earnings, if any. There is no information in the survey on after-tax income and earnings. Therefore, gross measures are used for the analysis. With respect to unemployment benefits, $10 \%$ of the households in the sample received some income from unemployment benefits, but they were the main source of income for only $2 \%$. About $2 \%$ of the sample received welfare benefits. We used a series of variables describing the source of household income to instrument non-labour income (see the discussion in Appendix C).

We constructed a series of dummies measuring the skill content of the occupation based on the occupational classification of the individuals. Because some of the women in the sample probably never worked, this was not available for about ten per cent of the wives in the sample (the estimation results were not substantially affected if these couples were dropped from the analysis).

For the diary information, the following should be noted:

- The interviewer chose the day for the diary to be filled in.

- Activities were recorded every ten minutes over a 24-hour period. 
- Main and secondary activities were coded. These latter are activities carried out simultaneously, such as cooking and watching the children, with the respondent deciding which activity was primary and which secondary.

- Around 140 main activity categories and 100 secondary activity categories were defined by the survey designers.

Here we only consider main activities. Only for childcare, did we compare the responses computed including both main and secondary activities. We sum total time spent on various activities, so that for example different spells of childcare time were added up to calculate total childcare time over the whole diary day.

We distinguish the following activities:

- Doing paid work, whether at home or at the office

- Childcare time, including taking (or time spent going with) the children somewhere and playing with the children.

- Household work, including cleaning, shopping, cooking, doing the laundry, washing up dishes, setting the table, and doing paperwork-where this last variable included, by sample design construction, time spent going to administrative offices.

- Household work as above and including also semi-leisure time, defined as making jam, knitting, gardening, household repairs, and taking pets out.

- Leisure time, including personal care time, own time and sleeping time.

\section{Descriptive statistics}

Sample descriptive statistics are provided in Table 2, both including and excluding couples who answered the diary at the weekend. The distribution of time use of the two spouses is shown in Table 3, for the whole sample, and in Table 4, excluding couples who answered the diary at the weekend.

About $80 \%$ of the couples in the sample were married and $26 \%$ had young children, aged less than three years. Roughly $20 \%$ lived in the region of Paris (Ile de France) 
but only $2 \%$ actually resided in inner Paris. Roughly $93 \%$ of the parents in the sample were French nationals. The average gross hourly wage rate was ten Euros for men and 8 Euros for women.

It is striking that about $50 \%$ of women and $75 \%$ of men did not spend any time with their children on the day the diary was filled in (restricting the sample to couples with young children, aged under three, produces lower figures of $3 \%$ for women and $34 \%$ for men, but with a far smaller sample size of 353 couples).

Women and, to a lesser extent, men perform more housework than childcare: at the median, women spend 50 minutes on childcare and 220 on housework, in the diary day; men spend 0 time on children and 30 minutes doing housework. This picture does not change much if a definition of childcare time including secondary activities is used. This is obviously due to the fact that $50 \%$ of the women in the sample did not perform any paid work. In addition to this, in France, childcare facilities, as well as maternal and elementary schools, are open about ten hours a day, which certainly reduces the time parents will spend with their children. It is, instead, likely that the presence of children in the household considerably increases the amount of time that people spend on activities such as shopping, cooking, washing up dishes and cleaning the house, which are difficult to delegate to others.

Interestingly, housework by men increases considerably if a broader definition of housework is adopted, including repairs, gardening and taking out pets; while the amount of housework carried out by women is left almost unchanged.

The distribution of the husband's share in the total time allocated by each two-parent couple to given activities in the day the diary was collected is shown in Table 5 , for the whole sample, and in Table 6, excluding couples who answered the diary at the weekend. Husbands account for a large share of paid work: husbands do all of the paid work in half of all couples. On the other hand, wives do a lot more of housework and childcare than do their husbands, although $10 \%$ of the husbands in our sample report more housework and childcare than their wives. All this, of course, depends on the particular day the diary was filled in, but since observations where the diary was filled in on an 'exceptional' day were dropped from the sample, we can reasonably assume that these refer to fairly 
'representative' days.

This evidence underlines the importance of modelling spouses' choice of time allocation taking non-participation into account, as we do in the empirical model. In particular, non-participation in paid work falls considerably for husbands when couples answering the diary at the weekend are excluded. We therefore focus on this sub-sample for the estimation of the model, in order to better capture the impact of wage rates on time allocation choices (see Table 7 and following). On the other hand, spouses spend more time on childcare and housework at weekends. We therefore also show model estimation results for the full sample in the Appendix (Tables A and B).

Finally, the correlation of usual hours of paid work, according to the individual questionaire, and diary paid work time is stronger when observations answering the diary at the weekend are excluded -and equal, respectively, to 0.53 for husbands and 0.71 for wives.

\section{Estimation Results}

The estimation results of the model for the sub-sample of couples answering the diary on a week day are presented in Tables 7,8 and $9 .{ }^{8}$ The correlations of the error terms of the wage equations and the other equations of the model are, generally, significant, confirming the importance of allowing for simultaneity.

\subsection{Wage rates and non-labour income}

The expected effects of changes in own and spouse's wage, and non-labour income, on spouses' time allocation were summarized in Table 1 . Table 7 shows the estimation results. The husband's wage rate has a positive and significant effect on his market work, and a negative effect on his non-market time. In particular, the effect of the husband's wage on own childcare is negative -although significant only at the ten per

\footnotetext{
8 Table 8 shows the estimates of the employment and wage equations. Employment increases significantly with occupational skills. The employment of women falls with the number of children. Greater non-labour income reduces employment for both men and women. The unemployment rate attracts a negative sign for both men and women, but its coefficient is not significant. Wage rates increase significantly with education and occupational skills.
} 
cent level, suggesting that the substitution effect dominates the income effect (see Table 1). The effect of the husband's own wage on housework is also negative, as expected.

Interestingly, the higher the wife's wage rate, the more time her husband spends on housework and childcare. However, women's childcare time is not sensitive to the own wage or to their husband's wage, suggesting here little scope for substitution of parents' time into the household production function. It is, instead, plausible that a higher female wage rate implies more negotiating power within the household, resulting thus in a little more housework and childcare being carried out by men.

There is a positive and significant effect of women's wages on their own paid work, as expected. The response of women's paid-work to their husband's wage is negative, but not significant. The effect of women's wages on own housework time is negative, as predicted, but insignificant. We find an insignificant negative impact of women's wages on own child care time.

Non-labour income has a significantly negative effect on the market labour supply of both parents, as predicted by the theory (see Table 1). The evidence generally supports the prediction that the income effect is positive: the estimated effect of non-labour income on childcare time is also positive. The estimated impact of non-labour income on non-market time is positive and statistically significant for men; it is positive but insignificant for women. For men, this is at odds with the zero prediction in Table 1, which is based on the standard assumptions that housework does not enter the utility function and that housework services bought in the market are perfect substitutes for home production. This suggests that individuals may enjoy the time spent, for example, cooking or shopping or checking their financial accounts, or may not perceive the market alternative as a perfect substitute for home consumption.

These findings are robust to using a different specification of housework, including 'semi-leisure activities' (see Tables 11, 12, 13 and 14). They are also robust to a different sample selections, including spouses that answered the time-diary over a weekend (see Table A in the Appendix) and to using a different definition of housework and including weekend-days diaries (see Table B in the Appendix). Moreover, they are robust to some sensitivity checks for possible measurement error in non-labour income (see Tables C 
and D).

\subsection{Elasticities}

To gain further insight into the impact of wage rates and non-labour income on time allocation decisions, we have computed the reponse of time use to a $1 \%$ rise in wages, in terms of elasticities (see Table 10). ${ }^{9}$ We also compute the impact of a change in wages on the total time allocated by spouses in each household on a given activity, by summing the husband's and wife's time.

We conclude that parents' paid work is more sensitive to their own wage than to their spouse's wage, in line with the findings in the labour-supply literature. In particular, the estimated cross-wages elasticities are very close to zero. The own wage elasticity is much larger for women than men: an increase of $1 \%$ in the wage rate of women would increase their market labour supply by $1.4 \%$, against $0.4 \%$ for the own-wage response of market work of men. An increase in non-labour income leads to a drop of paid work. The elasticity of paid-work time of both spouses to non-labour income is significantly negative but small.

The own-wage elasticity of husbands' housework is significantly negative, and the cross-wage elasticity is significantly positive. Increasing women's wage rate by $1 \%$ would lead to $0.5 \%$ more housework by men. The own-wage elasticity of women's housework is also significantly negative, but the cross-wage elasticity is almost zero. Non-labour income has a small and positive impact on husbands' housework, but this effect is insignificant for women.

Finally, the own wage elasticity of childcare is not statistically significant for either parent but the cross-wage elasticity is positive and strongly significant for fathers. An increase of $1 \%$ in the wage rate of women would increase their husbands' chidlcare time by $0.6 \%$. However, the wage elasticity for the household as a whole is negative and not

${ }^{9}$ We simulated the model given by Equation (11) 1000 times, using observed wages, whenever available, and simulated wages otherwise. To compute the elasticity of time allocation with respect to the husband's wage, we increase all husbands' wages by $1 \%$ and simulate the model again. We thus record the change in time for each activity for both men and women and compute the elasticity. The procedure is repeated for an increase in the wife's wages and, alternatively, non-labour income. The standard errors illustrate the variation in the elasticity which results from the use of parameter estimates. 
significant: the childcare time of men reacts positively to changes in the wage of their wife, but the total time spent on child care at the household level is not much affected. The elasticity of childcare time with respect to non-labour income is small and positive. It is statistically significant for women but less so for men.

Estimating the model adopting a broader definition of housework, which includes 'semi-leisure' activities, and/or using the full sample, including spouses that answered the diary at the weekend, did not affect substantially the results of estimation (see, respectively, Table 14, and Tables A and B in the Appendix to the paper). These findings are also robust to some sensitivity checks for possible measurement error in non-labour income (see Appendix C, Tables C and D).

\subsection{Effects of the other covariates on the time use allocation}

A number of remarks are worth making regarding the impact of the other covariates (see Table 7). First, housework time by women, is positively and significantly affected by marital status and the number of children while this is not so for men. ${ }^{10}$ Residing in the region of Paris ('Ile-de-France') significantly reduces the amount of time women spend on housework. ${ }^{11}$ Age and education do not directly influence the housework time of parents, with the exception of women with the highest education level who seem to spend more time on housework, compared to the reference category -but this effect is only significant at the ten per cent level.

The presence of children aged under three in the household significantly increases the time that parents spend on childcare. However, the estimated coefficient is twice as large for women as for men. In addition to this, the number of children significantly increases the time mothers spend with children or doing housework and reduces their market work, but the impact is not significant for men.

Higher-educated and older parents spend significantly more time caring for their chil-

\footnotetext{
${ }^{10}$ We do not make any attempt here to control for possible endogeneity of marital and fertility as there is no obvious way to do so. However, notice that all couples in our sample have children (by selection), $20 \%$ of them are not married and $26 \%$ have young children, aged less than three years. See El Lnhga and Moreau (2007) for an account of the differences in time allocation of married and unmarried couples in Germany.

11 The effect for men is also significantly negative, when a broader definition of housework is adopted (see Table 11). This is likely to reflect lifestyle differences.
} 
dren, with age having a non-linear impact (where the peak is reached at age 33 for men and 26 for women) and education showing the largest effect for the highest educated.

Interestingly, French nationality affects significantly and positively the market work of both parents but has no impact on non-market activities, possibly reflecting difficulties or discrimination against non-French nationals in the labour market rather than individual time choices. ${ }^{12}$

Living in small neighborhoods does not affect parents' time allocation. This may be because small neighborhoods are often located fairly close to big towns in France (in the sense of often being suburbs of towns), so that there is not much geographical dispersion in terms of mentality and culture.

\subsection{Correlation in unobservables between time uses}

The empirical model allows the errors of the three time-use equations, and the wage and employment equations of the spouses within each household to be correlated with each other. Table 9 shows the estimates of these correlations and their standard deviations. Correlations in unobservables are important in this type of model as they may capture factors like positive assortative mating and/or polarization of spouses' behaviour due to unobservable characteristics. For example, individuals may marry others who have similar (unobservable) characteristics -reflecting positive assortative mating- or both parents may like to work longer hours in market work -in line with the polarization of long hours of work at the household level, and contrary to the 'specialization' of one spouse in market work and the other in housework.

In the husband's time-use equations, unobservables in paid work correlate negatively with unobservables in non-market activities. This negative correlation is the strongest for housework time. This suggests that there are unobservable characteristics that either select men into market activities or into non-market activities. The correlation between the errors of childcare and housework for men is positive, indicating that husbands who perform more housework also tend to spend more time caring for children. For women,

\footnotetext{
12 The French nationality dummy in the employment equation is positive and strongly significant for women, but insignificant for men (see Table 8).
} 
we also find a significantly negative correlation between the unobservables in paid work and non-market activities, while the unobservables of childcare and housework time are positively correlated.

Regarding the correlations between the two spousal equations, there is a positive relationship between husband's and wife's paid work, supporting the 'polarization' hypothesis that in some households everyone works longer hours, and in others fewer. The unobservables in husband's and wife's wages are also significantly and positively correlated, so that there are common unobserved factors which drive up both spouses' market wages. Positive assortative mating, defined as a positive correlation between spouses' socio-economic characteristics, may lie behind these correlations.

Interestingly, the unobservables in the equation for the wife's paid work time correlate positively and significantly with the unobservables in husband's childcare time, suggesting that when the husband has an unobserved willingness or productivity to take care of children, his wife increases her paid work.

Finally, there is a significantly positive association between the unobservables in the time parents in each household spend on childcare. Since parental care is expected to increase children's human capital, this may have particular implications for welfare. The errors of spouses' housework equations are positively and significantly correlated, but only if a different definition of housework is adopted, which includes 'semi-leisure' activities, like doing household repairs, gardening and taking out pets (see Table 13).

\section{Conclusions}

This paper is focused on the time allocation of parents and on the impact of economic incentives.

We set up a stylized theoretical model of spouses' utility maximization that enables us to single out the theoretical predictions concerning wage and non-labour income effects on the supplies of market and non-market time. We distinguish three sorts of non-market time: leisure, childcare and housework.

The empirical model we specify is sufficiently general that we can test the validity 
of the predictions of the theoretical model. We simultaneously allow for a three-way time-use choice by spouses within each household, allowing for non-participation in each of them. Wage and employment equations are also estimated simultaneously. We exploit the richness of information collected by the 1998-99 French time-use survey to estimate the model. This asks questions on individual earnings, usual hours of work and total household income, in addition to collecting diary information on how household members allocate time to different activities. The time diary was collected for all individuals in the household, so that we have time-use information for both spouses in a couple.

The results of estimation generally confirm the theoretical predictions, with the main exception of the finding that non-labour income positively affects husbands' housework, thus not validating the standard hypothesis that individuals do not derive utility from housework. We conclude that parents' market time responds positively to changes in own wage, but not to their spouse's wage. The own wage elasticity of housework of fathers is significantly negative, while the cross-wage elasticity is positive and strongly significant. Women's housework responds negatively to changes in own wage but not to the husband's wage. Childcare time of parents does not react to own wage, but the cross-wage elasticity of childcare time is significantly positive for fathers. However, total household childcare time is not responsive to changes in the wage of either spouse.

We find significantly negative elasticities of spouses' paid work time to non-labour income, although the size of these elasticities is not particularly large. The elasticity of total housework done by the spouses to non-labour income is positive and significant at the ten per cent level, and that of total childcare is also positive and strongly significant.

There are significant and positive correlations across the errors of the two spouses' childcare equations. Since time spent with children by parents very likely adds to the children's human capital, this may increase overall inequality, especially as we also find that higher educated parents allocate significantly more time to childcare.

The correlations in spousal unobservable components are also positive and significant for paid work, wages, and for housework -if a different definition is adopted, including semi-leisure activities. Positive assortative mating, defined as a positive correlation between spouses' socio-economic characteristics, may lie behind these correlations: indi- 
viduals marry with others who have similar unobservable characteristics.

Finally, we conclude that higher-educated and older parents spend more time with their children and that formal marriage increases housework carried out by women.

\section{References}

Apps, P (2003), "Gender, Time Use and Models of the Household", IZA Working Paper No. 796, June.

Apps, P and Rees, R. (2002), "Household production, full consumption and the costs of children", Labour Economics, Vol. 8, pp.621-648.

Apps, P. F. and Rees, R. (1997), "Collective Labor Supply and Household Production", Journal of Political Economy, 105, 178-190.

Apps, P. F. and Rees, R. (1996), "Labor Supply, Household Production and Intra-Family Welfare Distribution", Journal of Public Economics, 60, 199209.

Becker, G. S. (1965), "A Theory of the Allocation of Time", The Economic Journal, Vol. 75, No. 299, pp. 493-517.

Becker, G. S. (1981), "A Treatise on the Family", Cambridge Ma: Harvard University Press.

Börsch-Supan, A. and V. Hajivassiliou (1993), "Smooth unbiased multivariate probability simulators for maximum likelihood estimation of limited dependent variable models", Journal of Econometrics, Vol. 58, nr. 3, pp.347-368.

Chiappori, P. -A. (1997), "Introducing Household Production in Collective Models of Labour Supply, Journal of Political Economy, Vol. 105, No. 1, pp. 191-209.

Connelly R. and Kimmel J. (2007), "Spousal Influences on Parents NonMarket Time Choices, IZA DP No. 2894 
El Lahga A.R. and Moreau N. (2007), "The Effects of Marriage on Couples Allocation of Time Between Market and Non-Market Hours, IZA DP No. 2619

Gronau, R. (1976), "Leisure, Home Production and Work. The theory of the allocation of time revisited", NBER Working paper No. 137, May.

Hersch, J. and Stratton, L. S.(1994), "Housework, Wages, and the Division of Housework Time for Employed Spouses", American Economic Review, Vol. 84, 2, pp. 120-125.

Kalenkoski, S., Ribar, D. S., and Stratton, L. S.(2008), "The influence of wages on parents' allocation of time to child care and market work in the United Kingdom", Journal of Population Economics, forthcoming.

Kooreman, P. and Kapteyn, A. (1987), "A disaggregated analysis of the allocation of time within the household", Journal of Political Economy, Vol. 95, No.2, pp. 223-249.

OECD (2001), Employment Outlook, "Balancing Work and Family Life: Helping Parents into Paid Employment, Chapter 4.

Pollak, R. A. (2005), "Bargainaing Power in Marriage: Earnings, Wage Rates and Household Production"? NBER Working Paper No. 11239, March.

\section{A First-order conditions for solving the model}

The household maximizes the function specified in Equation 8 subject to the constraints given by Equations 1, 2, 3, 4, 6, and 7 . Let $\lambda_{B}$ be the Lagrange multiplier for the household budget constraint, Equation 7 . We have the following first-order conditions: ${ }^{13}$

$$
\lambda \frac{\partial U_{m}}{\partial C_{m}}=\lambda_{B}
$$

\footnotetext{
13 The equations may be augmented with Kuhn-Tucker conditions for the non-negativity of time use, consumption and the production of services. For reasons of conciseness, we abstain from writing down the full set of Kuhn-Tucker conditions for non-negativity of outcomes. Rather, we highlight the interpretation of the first order conditions.
} 


$$
\begin{gathered}
(1-\lambda) \frac{\partial U_{f}}{\partial C_{f}}=\lambda_{B} \\
\lambda \frac{\partial U_{m}}{\partial C_{d}}+(1-\lambda) \frac{\partial U_{f}}{\partial C_{d}}=\lambda_{B} p_{d}, d=h, c \\
\lambda \frac{\partial U_{m}}{\partial t_{3 m}}+\lambda_{B} p_{c} \frac{\partial g_{c}}{\partial t_{3 m}}=\lambda_{B} w_{m} \\
(1-\lambda) \frac{\partial U_{f}}{\partial t_{3 f}}+\lambda_{B} p_{c} \frac{\partial g_{c}}{\partial t_{3 f}}=\lambda_{B} w_{f} \\
\lambda \frac{\partial U_{m}}{\partial l_{m}}=\lambda_{B} w_{m} \\
(1-\lambda) \frac{\partial U_{f}}{\partial l_{f}}=\lambda_{B} w_{f} \\
\frac{\partial g_{h}}{\partial t_{2 k}}=\frac{w_{k}}{p_{h}}, k=m, f
\end{gathered}
$$

Note that housework times $t_{2 m}$ and $t_{2 f}$ are set by Equation 23 such that the marginal productivity of time spent on housework is equal to the relative wage for both spouses. A corner solution at zero hours may occur for high wage-low productivity spouses. Having solved for $t_{2 m}$ and $t_{2 f}, C_{h h}$ follows from Equation 3. Note that Equations 16 through 22 , all implicitly define 'marginal-rate-of-substitution equals price ratio' relations. The Equations 16 through 22, together with the budget constraint, Equation 7, can be used to solve for private consumption $C_{m}$ and $C_{f}$, household services $C_{h m}$ bought from the market, childcare times $t_{3 m}$ and $t_{3 f}$, and child services, $C_{c h}$ and $C_{c m}$ (using Equations 2 and 4 ), leisure values $l_{m}$ and $l_{f}$, and the multiplier $\lambda_{B}$. Time spent on work follows from the time constraint Equation 6.

Equations 19 and 20 suggest that time caring for children not only depends on productivity and market prices (which also applies to housework time, Equation 23), but also on the resulting utility. If the marginal utility of the time spent caring for the children is positive, Equations 19 and 20 imply that the wage is larger than the marginal revenue product of childcare time. If the production function 4 has positive, but diminishing marginal productivity, this implies that someone who attaches positive utility to childcare time will spend more time on childcare than someone that does not value childcare (who has then zero marginal utility). 


\section{B Likelihood contributions}

To deal with the multidimensional integration of the likelihood contributions, we estimate the model by simulated maximum likelihood, using the GHK algorithm (see, for instance, Börsch-Supan and Hajivassiliou, 1993), proceeding as follows.

We write the variance-covariance matrix $\Sigma$ of the errors of the time-use, employment and wage equations as:

$$
\Sigma=\left(\begin{array}{ll}
A & C^{\prime} \\
C & \Omega
\end{array}\right)
$$

with

$$
\Omega=E u_{i} u_{i}^{\prime}, u_{i}=\left(\begin{array}{c}
u_{i m} \\
u_{i f}
\end{array}\right), C=E u_{i}\left(\begin{array}{c}
\epsilon_{i m} \\
\epsilon_{i f} \\
\nu_{i m} \\
\nu_{i f}
\end{array}\right)^{\prime}, A=E\left(\begin{array}{l}
\epsilon_{i m} \\
\epsilon_{i f} \\
\nu_{i m} \\
\nu_{i f}
\end{array}\right)\left(\begin{array}{l}
\epsilon_{i m} \\
\epsilon_{i f} \\
\nu_{i m} \\
\nu_{i f}
\end{array}\right)^{\prime}
$$

The joint density of the errors of the time-use equations (Equation 11) and the employment equations (Equation 13), conditional on the errors of the wage equations (Equation 12 ), is normal with mean $B_{i}$ and variance-covariance matrix $Z$, with:

$$
B_{i}=C^{\prime} \Omega^{-1} u_{i}, Z=A-C^{\prime} \Omega^{-1} C
$$

Let $L$ be the lower-triangular matrix implicitly defined by:

$$
L L^{\prime}=Z
$$

with typical element $l_{j s}, j=1, \ldots 8, s=1, \ldots, j$. For each household, we draw $R$ independent random numbers $u_{i s r}^{*}, i=1, \ldots, N, s=1, \ldots, 7, r=1, \ldots, R$ from the uniform distribution over the range $(0,1)$. These random numbers are used to recursively simulate the likelihood contributions for the time-use equations of the husband, the time-use equations of the wife, and the employment equations of husband and wife. We initially assume that wages $w_{i m}$ and $w_{i f}$ are observed. Let $l_{i t m j r}$ denote the simulated likelihood contribution for the $j$-th time use $(j=1,2,3)$ of the husband in household $i$, and replication $r$. If the husband reports no time spent on time use $j(j=1,2,3)$ we set $^{14}$

$$
l_{i t m j r}=\Phi\left(-\frac{\alpha_{j m}^{m} \ln w_{i m}+\alpha_{j m}^{f} \ln w_{i f}+x_{i m}^{\prime} \beta_{j m}+\sum_{s=1}^{j-1} l_{j s} \nu_{i s r}}{l_{j j}}\right)
$$

\footnotetext{
${ }^{14}$ We define the summation $\sum_{s=1}^{0} \equiv 0$.
} 
and

$$
\nu_{i j r}=\Phi^{-1}\left(l_{i t m j r} u_{i j r}^{*}\right)
$$

where $\Phi($.$) represents the standard normal distribution function. If the husband reports$ a positive amount of time spent on activity $j$, we set $l_{i t m j r}=$

$$
\frac{1}{l_{j j}} \phi\left(\frac{t_{i j m}-\left[\alpha_{j m}^{m} \ln w_{i m}+\alpha_{j m}^{f} \ln w_{i f}+x_{i m}^{\prime} \beta_{j m}+\sum_{s=1}^{j-1} l_{j s} \nu_{i s r}\right]}{l_{j j}}\right)
$$

where $\phi($.$) is the standard normal density function, and$

$$
\nu_{i j r}=\frac{t_{i j m}-\left[\alpha_{j m}^{m} \ln w_{i m}+\alpha_{j m}^{f} \ln w_{i f}+x_{i m}^{\prime} \beta_{j m}+\sum_{s=1}^{j-1} l_{j s} \nu_{i s r}\right]}{l_{j j}}
$$

We take an analogous approach for the time use of the wife. If the wife reports no time spent on activity $j$, we determine:

$$
l_{i t f j r}=\Phi\left(-\frac{\alpha_{j f}^{m} \ln w_{i m}+\alpha_{j f}^{f} \ln w_{i f}+x_{i f}^{\prime} \beta_{j f}+\sum_{s=1}^{j+3-1} l_{j s} \nu_{i s r}}{l_{j+3, j+3}}\right)
$$

and

$$
\nu_{i, j+3, r}=\Phi^{-1}\left(l_{i t f j r} u_{i, j+3, r}^{*}\right)
$$

If the wife reports a positive amount of time spent on activity $j$, we have $l_{i t f j r}=$

$$
\frac{1}{l_{j+3, j+3}} \phi\left(\frac{t_{i j f}-\left[\alpha_{j f}^{m} \ln w_{i m}+\alpha_{j f}^{f} \ln w_{i f}+x_{i f}^{\prime} \beta_{j f}+\sum_{s=1}^{j+3-1} l_{j s} \nu_{i s r}\right]}{l_{j+3, j+3}}\right)
$$

and

$$
\nu_{i, j+3, r}=\frac{t_{i j f}-\left[\alpha_{j f}^{m} \ln w_{i m}+\alpha_{j f}^{f} \ln w_{i f}+x_{i f}^{\prime} \beta_{j f}+\sum_{s=1}^{j+3-1} l_{j s} \nu_{i s r}\right]}{l_{j+3, j+3}}
$$

The likelihood contribution for the employment status of the husband, denoted by $l_{\text {iemr }}$, is equal to, for a non-employed husband:

$$
l_{i e m r}=\Phi\left(-\frac{q_{i m}^{\prime} \gamma_{m}+\sum_{s=1}^{6} l_{7 s} \nu_{i s r}}{l_{77}}\right)
$$

and

$$
\nu_{i 7 r}=\Phi^{-1}\left(l_{i e m r} u_{i 7 r}^{*}\right)
$$

For an employed husband, it is equal to:

$$
l_{i e m r}=1-\Phi\left(-\frac{q_{i m}^{\prime} \gamma_{m}+\sum_{s=1}^{6} l_{7 s} \nu_{i s r}}{l_{77}}\right)
$$




$$
\nu_{i 7 r}=\Phi^{-1}\left(\left(1-l_{i e m r}\right)+l_{i e m r} u_{i 7 r}^{*}\right)
$$

For the employment of the wife, we set the likelihood contribution $l_{\text {iefr }}$ if she is nonemployed equal to:

$$
l_{i e f r}=\Phi\left(-\frac{q_{i f}^{\prime} \gamma_{f}+\sum_{s=1}^{7} l_{8 s} \nu_{i s r}}{l_{88}}\right)
$$

If she is employed, we set this equal to:

$$
l_{i e f r}=1-\Phi\left(-\frac{q_{i f}^{\prime} \gamma_{f}+\sum_{s=1}^{7} l_{8 s} \nu_{i s r}}{l_{88}}\right)
$$

Next, we set the simulated likelihood contribution of household $i$, for replication $r$ of the time-use equations and employment status equal to $l_{i r}$, where

$$
l_{i r}=\prod_{j=1}^{3} l_{i t m j r} l_{i t f j r} l_{i e m r} l_{i e f r}
$$

This is then averaged over replications to yield:

$$
l_{i}=\frac{1}{R} \sum_{r=1}^{R} l_{i r}
$$

In the empirical application we set $R=60$.

Were neither the wage rates of the husband or the wife to be observed, before computing the above likelihood contributions we simulated their wages $w_{i m r}$ and $w_{i f r}$, by drawing them from their joint distribution, (defined by Equation(12) and $u_{i} \sim N(0, \Omega)$ ), and then plugged them into the simulated likelihood contributions listed above. If the wage rate of the husband is observed, but that of his wife is not, we draw the wife's wage rate, $w_{i f r}$, from the distribution of $w_{i f}$, conditional on $w_{i m}$, and plug it into the simulated likelihood contribution, as above. The likelihood contribution was completed by multiplying Equation 43 by the marginal density of the husband's wage rate. For households, where, on the contrary, the wife's wage rate was observed but the husband's was not, we proceed similarly. If both wage rates are observed, we multiply the simulated likelihood contribution Equation 43 by the joint density function of the wife's and husband's wage rates. 


\section{Additional robustness checks: allowing for mea- surement error in non-labour income}

Additional sensitivity checks were performed to test whether any possible correlation of non-labour income with the error terms of the time-use equations affects the outcomes of the model. Since non-labour income is the difference between total household income and the sum of the earnings of the spouses, possible measurement error in earnings may affect non-labour income as well. Re-estimating the model without non-labour income provides a first check. If measurement error in non-labour income is important, it will also affect the parameter estimates of the other variables, and in particular the wage elacticities of the time uses. We have re-estimated the model for our base variant (week diaries only, conventional definition of housework time). The resulting elasticities are shown in Table $\mathrm{C}$ in the Appendix. ${ }^{15}$ We conclude that there are no large differences in the estimated elasticities when including (Table 10) or excluding (Table C) non-labour income. The most affected are the elasticities of the housework time of the husband, which are smaller when non-labour income is dropped from the model. However, on the basis of the confidence intervals for the different estimates of the elasticities, the elasticities are well within each other's confidence intervals.

Next to this, we have instrumented non-labour income. To avoid the weak instruments problem, we have done first stage regressions to select predictors for non-labour income. We use than a dummy for the presence of 'housing and financial rents' and 'other revenues' as a source of household income; and a dummy variable indicating whether the household has positive non-labour income. ${ }^{16}$ Next, we have added this equation for non-labour income to the system of Equations 11, 12, and 13, and we estimated this extended system simultaneously. ${ }^{17}$ The joint system allows for correlation between the

\footnotetext{
${ }^{15}$ A full set of estimates is available from the authors upon request.

16 This dummy indicator is much less sensitive to possible measurement error in earnings than the the continuous measure of non-labour income. Without this indicator, the R-squared of the regression for non-labour income did not exceed 0.05, which makes it virtually impossible to instrument non-labour income, as with such a low R-squared the non-labour income strongly correlates with its residual. Including the indicator for positive non-labour income increases the R-squared to 0.27.

17 The equation for non-labour income is purely meant as a statistical, 'instrumental', equation. We do not interpret it as a 'structural' equation, representing the formation of non-labour income. The latter is a topic beyond the scope of this static time allocation framework. We included the aforementioned
} 
errors of the equation for non-labour income and the errors of the time-use equations, the employment equations, and the wage equations. We did a likelihood ratio rest to test the null hypothesis that the (ten) correlation coefficients are (jointly) equal to zero. In particular, we are interested in the sign and significance of the correlations between the errors of the equation for non-labour income and the time-use equations: non-zero correlations would suggest that measurement error in non-labour income may bias the results. The value of the likelihood ratio test statistic is 31.4. The critical value for a chi-squared test statistic with 10 degrees of freedom is 18.3. Thus, the null hypothesis that the entire vector of correlation coefficients between the errors of the equation for non-labour income and the errors of the rest of the system is equal to zero is rejected. However, inspection of the separate correlation coefficients shows that only two correlation coefficients have t-values larger than 2. These are the correlations between the equation for non-labour income and the employment equations. For the remaining, only the correlation between non-labour income and the paid work equation for women is significant at the 10 per cent level, according to its t-value. Six of the correlation coefficients show a t-value that is smaller than one. We next re-estimated the model, restricting the seven insignificant correlation coefficients to zero, and leaving unrestricted the correlations between the errors of the equation for non-labour income, the employment equations and the equation for paid work of women. The likelihood ratio test statistic for testing whether these 3 correlation coefficients are (jointly) equal to zero takes the value 25.9 , which leads to a clear rejection at the 5 percent level (the critical value is 7.8 ). The likelihood ratio test statistic for testing the validity of setting the remaining 7 correlation coefficients equal to zero, takes the value 5.5. The critical value for this test at the 5 per cent level is 14.1, so here the null hypothesis is not rejected. The correlations between the errors of non-labour income and employment (and paid work of the wife) are positive, indicating that there are unobservable factors that go together with both a higher employment probability and a higher non-labour income. ${ }^{18}$ For this final specification, we compute

indicators for non-labour income, the logarithm of the age of the husband and its square, and the number of children. Other regressors were not significant at the 5 percent level in the first stage regression, and have not been included to avoid the weak instruments problem.

18 Thus, the results show that only the coefficients of non-labour income in the employment equations are biased if non-labour income is not instrumented. Without instrumenting, the coefficient of 
the wage and income elasticities of the time-use equations (see Table D). The results for the elasticities are hardly different from those of our preferred specification reported in Table 10. The largest (relative) difference is found for the elasticities of paid work of the wife with respect to non-labour income: this elasticity gets somewhat smaller (i.e. more negative). However, the two different values of the elasticities would still be included in each other's 5 percent's confidence interval based on their standard errors.

non-labour income in the employment equation measures both a 'true' causal effect of non-labour income on employment, which must be negative, and an offsetting positive correlation in unobservables. Incorporating correlation of non-labour income with the error term of the employment equation gives a smaller (i.e. more negative) coefficient of non-labour income in the employment equation, whereas the positive effect in unobservables is captured by a positive estimate of the correlation coefficient. 
Table 1: Theoretical effects of wages and non-labour income on spouses' time allocation

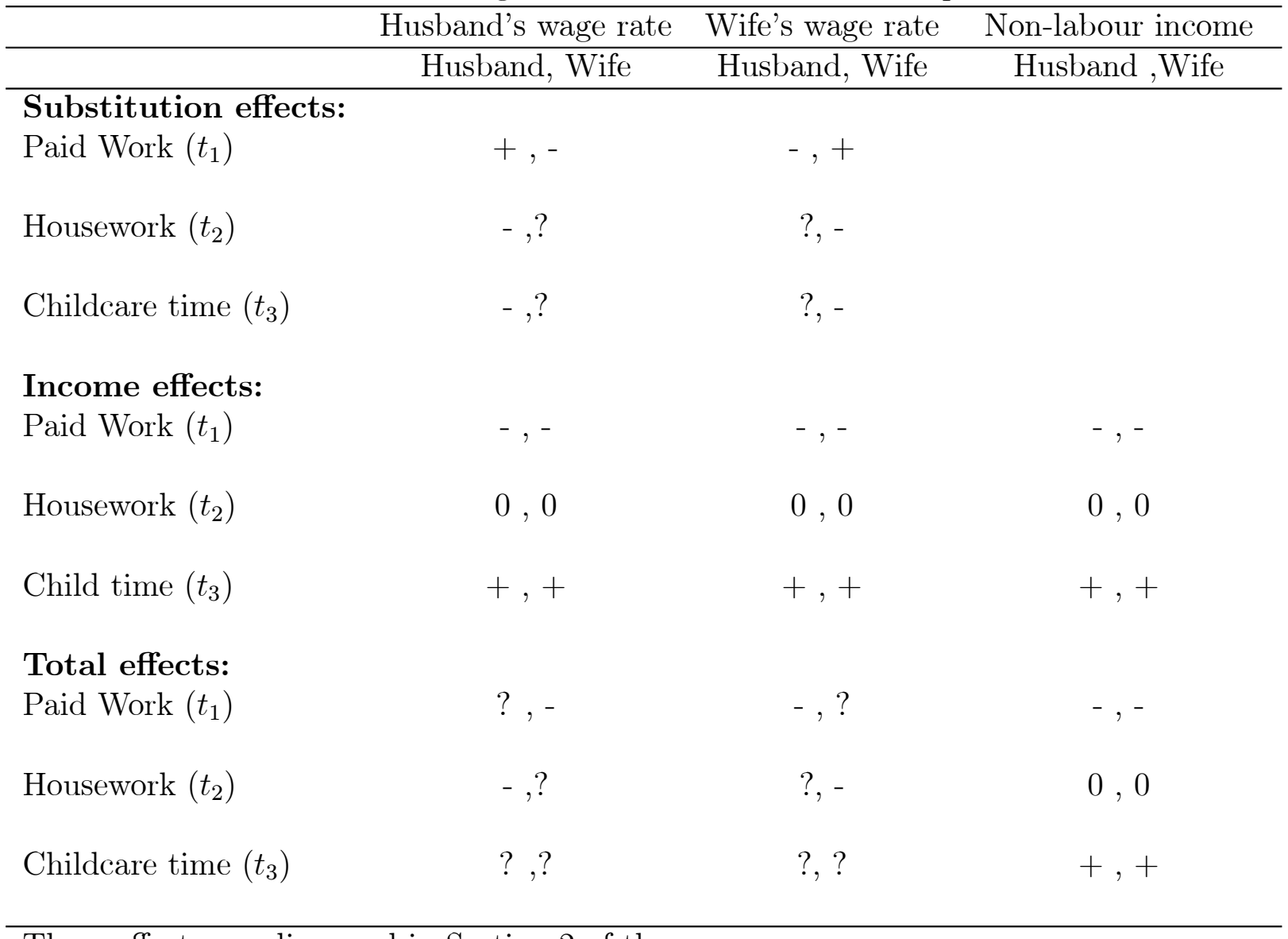

These effects are discussed in Section 2 of the paper. 
Table 2: Sample descriptives

\begin{tabular}{lrrrr}
\hline Variable & \multicolumn{2}{l}{ Full Sample } & \multicolumn{2}{c}{ Excluding } \\
& \multicolumn{2}{c}{$N=1473$} & \multicolumn{2}{c}{$N=1080$} \\
\hline & Mean & Std Dev & Mean & Std Dev \\
\hline W Age & 37.80 & 7.46 & 37.84 & 7.53 \\
H Age & 40.26 & 7.74 & 40.27 & 7.86 \\
W Compulsory education & 0.11 & 0.31 & 0.11 & 0.31 \\
W Lower Secondary & 0.28 & 0.45 & 0.28 & 0.45 \\
W Upper Secondary & 0.15 & 0.35 & 0.15 & 0.36 \\
W University short degree & 0.12 & 0.32 & 0.12 & 0.32 \\
W University degree and higher & 0.09 & 0.29 & 0.10 & 0.29 \\
H Compulsory education & 0.07 & 0.26 & 0.07 & 0.26 \\
H Lower Secondary & 0.38 & 0.48 & 0.38 & 0.48 \\
H Upper Secondary & 0.09 & 0.29 & 0.08 & 0.28 \\
H University short degree & 0.10 & 0.30 & 0.11 & 0.31 \\
H University degree and higher & 0.12 & 0.33 & 0.12 & 0.33 \\
W High-skilled occupation & 0.08 & 0.27 & 0.08 & 0.28 \\
W Intermediary occupation & 0.18 & 0.39 & 0.18 & 0.38 \\
W Low-Skill occupation & 0.55 & 0.50 & 0.54 & 0.50 \\
W Unskilled occupation & 0.09 & 0.28 & 0.09 & 0.29 \\
W occupational skill n. a. & 0.10 & 0.30 & 0.10 & 0.31 \\
H High-skilled occupation & 0.19 & 0.39 & 0.20 & 0.40 \\
H Intermediary occupation & 0.24 & 0.43 & 0.23 & 0.42 \\
H Low-Skill occupation & 0.45 & 0.50 & 0.45 & 0.50 \\
H Unskilled occupation & 0.11 & 0.31 & 0.12 & 0.32 \\
Married & 0.82 & 0.38 & 0.83 & 0.37 \\
No. of children & 1.93 & 1.00 & 1.91 & 0.98 \\
Children, age < 3 & 0.26 & 0.47 & 0.26 & 0.47 \\
Ile de France & 0.19 & 0.39 & 0.20 & 0.40 \\
Paris & 0.02 & 0.14 & 0.02 & 0.15 \\
W French nationality & 0.93 & 0.26 & 0.93 & 0.25 \\
H French nationality & 0.92 & 0.27 & 0.93 & 0.26 \\
\hline & & & &
\end{tabular}


Table 2: Sample descriptives (continued)

\begin{tabular}{|c|c|c|c|c|}
\hline \multirow[t]{2}{*}{ Variable } & \multicolumn{2}{|c|}{$\begin{array}{l}\text { Full Sample } \\
\qquad N=1473\end{array}$} & \multicolumn{2}{|c|}{$\begin{array}{l}\text { Excluding } \\
\text { weekend diaries } \\
\qquad N=1080\end{array}$} \\
\hline & Mean & Std Dev & Mean & Std Dev \\
\hline W Employed & 0.62 & 0.48 & 0.62 & 0.48 \\
\hline H Employed & 0.91 & 0.29 & 0.90 & 0.29 \\
\hline W Hours of work per week & 18.78 & 17.52 & 18.45 & 17.42 \\
\hline H Hours of work per week & 33.66 & 13.20 & 33.59 & 13.24 \\
\hline W Hours of work per week, diary & 13.12 & 18.07 & 16.77 & 19.03 \\
\hline H Hours of work per week, diary & 25.35 & 21.31 & 32.76 & 18.81 \\
\hline W Household work, minutes, diary & 233.58 & 131.94 & 227.99 & 134.51 \\
\hline H Household work, minutes, diary & 60.94 & 80.32 & 50.18 & 73.07 \\
\hline W Household work broad, diary & 253.22 & 143.41 & 246.13 & 146.88 \\
\hline H Household work broad, diary & 123.00 & 141.61 & 104.12 & 134.95 \\
\hline W Childcare, primary activity, diary & 83.62 & 95.43 & 89.43 & 98.96 \\
\hline H Childcare, primary activity, diary & 28.83 & 53.35 & 26.32 & 46.96 \\
\hline W hourly wage, Euros & 8.43 & 5.35 & 8.53 & 5.61 \\
\hline H hourly wage, Euros & 10.0 & 5.70 & 10.01 & 5.55 \\
\hline Household non-labour income, monthly & 484.39 & 697.91 & 496.39 & 721.24 \\
\hline Regional unemployment rate & 11.35 & 2.41 & & \\
\hline \multicolumn{5}{|c|}{$\begin{array}{l}\text { These are unweighted sample statistics. } \\
\text { The diary paid work activity is actually recorded in minutes per day, but we have } \\
\text { transformed it here in hours per week, to compare it to the standard usual hours } \\
\text { from the individual questionnaire. }\end{array}$} \\
\hline
\end{tabular}


Table 3: Distribution of spouses' time allocation

\begin{tabular}{lrrrr}
\hline Percentiles & \multicolumn{5}{c}{ Sample } & \multicolumn{3}{c}{. } & \\
\hline Percentiles & Paid work & Childcare & Housework & Housework broad \\
\hline Wives 1\% & 0 & 0 & 0 & 0 \\
$5 \%$ & 0 & 0 & 40 & 40 \\
$10 \%$ & 0 & 0 & 60 & 60 \\
$25 \%$ & 0 & 0 & 130 & 140 \\
$50 \%$ & 0 & 50 & 220 & 240 \\
$75 \%$ & 390 & 130 & 330 & 360 \\
$90 \%$ & 500 & 210 & 410 & 450 \\
$95 \%$ & 530 & 270 & 460 & 510 \\
$99 \%$ & 620 & 380 & 550 & 600 \\
\hline Husbands $1 \%$ & 0 & 0 & 0 & 0 \\
$5 \%$ & 0 & 0 & 0 & 0 \\
$10 \%$ & 0 & 0 & 0 & 0 \\
$25 \%$ & 0 & 0 & 0 & 70 \\
$50 \%$ & 440 & 0 & 30 & 180 \\
$75 \%$ & 510 & 40 & 90 & 340 \\
$90 \%$ & 590 & 90 & 170 & 430 \\
$95 \%$ & 630 & 140 & 230 & 600 \\
$99 \%$ & 740 & 250 & 350 & \\
\hline These are unweighted sample statistics. &
\end{tabular}

Table 4: Distribution of spouses' time allocation Percentiles Excluding weekend diaries

\begin{tabular}{lrrrr}
\multicolumn{5}{c}{$N=1078$} \\
\hline Percentiles & Paid work & Childcare & Housework & Housework broad \\
\hline Wives 1\% & 0 & 0 & 0 & 0 \\
$5 \%$ & 0 & 0 & 30 & 30 \\
$10 \%$ & 0 & 0 & 60 & 60 \\
$25 \%$ & 0 & 0 & 130 & 130 \\
$50 \%$ & 0 & 60 & 220 & 230 \\
$75 \%$ & 460 & 140 & 330 & 350 \\
$90 \%$ & 510 & 230 & 410 & 450 \\
$95 \%$ & 540 & 290 & 460 & 510 \\
$99 \%$ & 640 & 400 & 550 & 610 \\
\hline Husbands 1\% & 0 & 0 & 0 & 0 \\
$5 \%$ & 0 & 0 & 0 & 0 \\
$10 \%$ & 0 & 0 & 0 & 0 \\
$25 \%$ & 270 & 0 & 0 & 10 \\
$50 \%$ & 480 & 0 & 20 & 60 \\
$75 \%$ & 540 & 30 & 70 & 140 \\
$90 \%$ & 600 & 90 & 150 & 310 \\
$95 \%$ & 660 & 130 & 210 & 400 \\
$99 \%$ & 750 & 200 & 340 & 610 \\
\hline These are unweighted sample statistics. & & \\
\hline
\end{tabular}


Table 5: Share of husband's time allocation in each couple's total time in the activity

\begin{tabular}{lrrrr}
\hline Percentiles & Sample & & \\
& \multicolumn{5}{c}{$N=1473$} \\
\hline Husband's Share of time & Paid work & Childcare & Housework & Housework (broad) \\
\hline $1 \%$ & 0 & 0 & 0 & 0 \\
$5 \%$ & 11.11 & 0 & 0 & 0 \\
$10 \%$ & 50 & 0 & 0 & 0 \\
$25 \%$ & 67.14 & 0 & 0 & 6.25 \\
$50 \%$ & 100 & 12.5 & 13.04 & 26.83 \\
$75 \%$ & 100 & 40.82 & 33.33 & 46.48 \\
$90 \%$ & 100 & 75 & 51.03 & 61.54 \\
$95 \%$ & 100 & 100 & 63.64 & 73.53 \\
$99 \%$ & 100 & 100 & 100 & 100 \\
\hline Observations & 1033 & 1084 & 1470 & 1471 \\
\hline
\end{tabular}

These ratios of husband's time over couples' time are computed

only for couples where at least one of the two spouses participates in the activity.

Table 6: Share of husband's time allocation in each couple's total time in the activity

\begin{tabular}{lrrrr}
\hline \multicolumn{5}{c}{ Excluding weekend diaries } \\
\multicolumn{5}{c}{$N=1078$} \\
\hline Husband's Share of time & Paid work & Childcare & Housework & Housework (broad) \\
\hline $1 \%$ & 0 & 0 & 0 & 0 \\
$5 \%$ & 0 & 0 & 0 & 0 \\
$10 \%$ & 41.54 & 0 & 0 & 0 \\
$25 \%$ & 50.52 & 0 & 6.2 & 2.78 \\
$50 \%$ & 66.05 & 10 & 10 & 22.65 \\
$75 \%$ & 100 & 38.46 & 31.25 & 42.97 \\
$90 \%$ & 100 & 72.73 & 50 & 62.5 \\
$95 \%$ & 100 & 100 & 66.66 & 75 \\
$99 \%$ & 100 & 100 & 100 & 100 \\
\hline Observations & 923 & 817 & 1076 & 1076 \\
\hline These ratios of husband's time over couples' time are computed \\
only for couples where at least one of the two spouses participates in the activity. \\
\hline \multicolumn{5}{c}{} \\
\hline
\end{tabular}


Table 7: Estimates of time-use equations

Only weekday diaries, $N=1080$

\begin{tabular}{|c|c|c|c|c|c|c|}
\hline & \multicolumn{3}{|c|}{ Husbands } & \multicolumn{3}{|c|}{ Wives } \\
\hline Variable & Paid & House & Child & Paid & House & Child \\
\hline \multirow{2}{*}{$\begin{array}{c}\text { Log wage rate } \\
\text { husband }\end{array}$} & $2.92^{* *}$ & $-0.92^{* *}$ & $-0.65^{*}$ & -1.09 & -0.05 & -0.07 \\
\hline & (1.01) & $(0.41)$ & $(0.38)$ & $(0.69)$ & $(0.24)$ & $(0.23)$ \\
\hline \multirow{2}{*}{$\begin{array}{l}\text { Log wage rate } \\
\text { wife }\end{array}$} & -0.05 & $0.74^{* *}$ & $0.63^{* *}$ & $8.07 * *$ & $-3.06^{* *}$ & -0.67 \\
\hline & $(0.66)$ & $(0.24)$ & $(0.23)$ & $(2.07)$ & $(0.69)$ & $(0.47)$ \\
\hline \multirow[t]{2}{*}{ Intercept } & $-71.54^{*}$ & -19.72 & $-44.19^{* *}$ & $-155.73^{* *}$ & 25.38 & $-50.79 * *$ \\
\hline & $(43.36)$ & $(17.68)$ & $(15.82)$ & $(38.91)$ & $(16.84)$ & $(11.83)$ \\
\hline \multirow[t]{2}{*}{ Log age } & 38.11 & 11.00 & $25.20^{* *}$ & $75.75^{* *}$ & -9.22 & $33.16^{* *}$ \\
\hline & $(23.80)$ & $(9.71)$ & $(8.73)$ & $(21.46)$ & $(9.26)$ & $(6.73)$ \\
\hline \multirow[t]{2}{*}{ Log age squared } & -5.56 & -1.43 & $-3.65^{* *}$ & $-10.76^{* *}$ & 1.73 & $-5.11^{* *}$ \\
\hline & $(3.24)$ & (1.32) & (1.19) & (3.00) & $(1.29)$ & $(0.95)$ \\
\hline \multirow[t]{2}{*}{ Compulsory ed. } & -0.78 & $0.54^{* *}$ & $0.54^{* *}$ & 0.99 & 0.09 & 0.01 \\
\hline & $(0.71)$ & $(0.26)$ & $(0.26)$ & $(0.87)$ & $(0.29)$ & $(0.25)$ \\
\hline \multirow[t]{2}{*}{ Low secondary } & 0.04 & 0.20 & $0.40^{* *}$ & -0.15 & 0.20 & $0.40^{* *}$ \\
\hline & $(0.43)$ & $(0.18)$ & $(0.17)$ & $(0.79)$ & $(0.27)$ & $(0.20)$ \\
\hline \multirow[t]{2}{*}{ Upper secondary } & -0.47 & 0.25 & $0.53^{* *}$ & -1.16 & 0.29 & $1.00^{* *}$ \\
\hline & $(0.71)$ & $(0.30)$ & $(0.25)$ & (1.04) & $(0.38)$ & $(0.25)$ \\
\hline \multirow{2}{*}{ Univers. short } & -0.56 & 0.23 & 0.51 & -0.91 & 0.72 & $0.69^{*}$ \\
\hline & $(0.87)$ & $(0.38)$ & $(0.32)$ & $(1.59)$ & $(0.54)$ & $(0.39)$ \\
\hline \multirow[t]{2}{*}{ Univers. and higher } & -0.83 & 0.57 & $1.05^{* *}$ & -3.02 & $1.38^{*}$ & $1.17^{* *}$ \\
\hline & $(1.06)$ & $(0.43)$ & $(0.37)$ & $(2.20)$ & $(0.75)$ & $(0.50)$ \\
\hline \multirow[t]{2}{*}{ Married } & 0.56 & -0.18 & -0.16 & -0.41 & $0.52^{* *}$ & -0.09 \\
\hline & $(0.40)$ & $(0.17)$ & $(0.17)$ & $(0.56)$ & $(0.22)$ & $(0.16)$ \\
\hline \multirow[t]{2}{*}{ French national } & $1.52^{* *}$ & -0.11 & 0.21 & $2.55^{* *}$ & -0.41 & 0.11 \\
\hline & $(0.61)$ & $(0.26)$ & $(0.25)$ & $(1.01)$ & $(0.29)$ & $(0.28)$ \\
\hline \multirow[t]{2}{*}{ Children, age $<3$} & -0.06 & 0.08 & $0.63^{* *}$ & $-1.66^{* *}$ & -0.12 & $1.29^{* *}$ \\
\hline & $(0.44)$ & $(0.18)$ & $(0.16)$ & $(0.62)$ & $(0.23)$ & $(0.16)$ \\
\hline \multirow[t]{2}{*}{ No. of children } & 0.22 & -0.03 & 0.09 & $-1.54^{* *}$ & $0.35^{* *}$ & $0.52^{* *}$ \\
\hline & $(0.17)$ & $(0.07)$ & $(0.07)$ & $(0.27)$ & $(0.07)$ & $(0.06)$ \\
\hline \multirow[t]{2}{*}{ Ile de France } & 0.23 & -0.05 & 0.16 & 0.49 & $-0.46^{* *}$ & 0.08 \\
\hline & $(0.46)$ & $(0.16)$ & $(0.15)$ & $(0.57)$ & $(0.19)$ & $(0.15)$ \\
\hline \multirow[t]{2}{*}{ Non-labour income } & $-0.25^{* *}$ & $0.04^{* *}$ & $0.03^{* *}$ & $-0.17^{* *}$ & 0.02 & $0.03^{* *}$ \\
\hline & $(0.04)$ & $(0.01)$ & $(0.01)$ & $(0.05)$ & $(0.02)$ & $(0.01)$ \\
\hline \multirow[t]{2}{*}{ Rural } & -0.27 & 0.18 & 0.04 & -0.82 & 0.13 & 0.00 \\
\hline & $(0.41)$ & $(0.16)$ & $(0.15)$ & $(0.55)$ & $(0.18)$ & $(0.16)$ \\
\hline
\end{tabular}


Table 8: Estimates of the employment and wage equations Only weekday diaries, $N=1080$

\begin{tabular}{|c|c|c|c|c|}
\hline \multirow{2}{*}{ Variable } & \multicolumn{2}{|c|}{$\begin{array}{c}\text { Employment } \\
\text { equations }\end{array}$} & \multicolumn{2}{|c|}{$\begin{array}{c}\text { Wage } \\
\text { equations }\end{array}$} \\
\hline & Husbands & Wives & Husbands & Wives \\
\hline \multirow[t]{2}{*}{ Intercept } & -11.10 & $-36.18^{* *}$ & 2.55 & 3.00 \\
\hline & $(23.87)$ & $(8.14)$ & $(2.16)$ & $(2.43)$ \\
\hline \multirow[t]{2}{*}{ Log age } & 7.67 & $20.10^{* *}$ & 0.11 & -0.31 \\
\hline & (13.04) & $(4.55)$ & $(1.19)$ & (1.34) \\
\hline \multirow[t]{2}{*}{ Log age squared } & -1.15 & $-2.76^{* *}$ & 0.05 & 0.12 \\
\hline & $(1.77)$ & $(0.63)$ & $(0.16)$ & $(0.18)$ \\
\hline \multirow[t]{2}{*}{ Compulsory ed. } & 0.48 & $0.55^{* *}$ & $0.13^{* *}$ & $0.14^{* *}$ \\
\hline & $(0.41)$ & $(0.17)$ & $(0.03)$ & $(0.03)$ \\
\hline \multirow[t]{2}{*}{ Low secondary } & 0.30 & $0.34^{* *}$ & $0.11^{* *}$ & $0.19^{* *}$ \\
\hline & $(0.23)$ & $(0.14)$ & $(0.02)$ & $(0.03)$ \\
\hline \multirow[t]{2}{*}{ Upper secondary } & $0.73^{*}$ & 0.26 & $0.12^{* *}$ & $0.29^{* *}$ \\
\hline & $(0.39)$ & $(0.17)$ & $(0.03)$ & $(0.03)$ \\
\hline \multirow[t]{2}{*}{ Univers. short } & 0.47 & 0.32 & $0.25^{* *}$ & $0.44^{* *}$ \\
\hline & $(0.41)$ & $(0.22)$ & $(0.03)$ & $(0.04)$ \\
\hline \multirow[t]{2}{*}{ Univers. and higher } & 0.60 & 0.18 & $0.34^{* *}$ & $0.58^{* *}$ \\
\hline & $(0.46)$ & $(0.31)$ & $(0.03)$ & $(0.04)$ \\
\hline \multirow[t]{2}{*}{ Married } & 0.19 & 0.01 & & \\
\hline & $(0.24)$ & $(0.14)$ & & \\
\hline \multirow[t]{2}{*}{ French national } & 0.34 & $0.50^{* *}$ & & \\
\hline & $(0.28)$ & $(0.21)$ & & \\
\hline \multirow[t]{2}{*}{ Children, age $<3$} & -0.30 & -0.26 & & \\
\hline & $(0.23)$ & $(0.15)$ & & \\
\hline \multirow[t]{2}{*}{ No. of children } & 0.11 & $-0.39^{* *}$ & & \\
\hline & $(0.08)$ & $(0.06)$ & & \\
\hline \multirow[t]{2}{*}{ Ile de France } & -0.13 & 0.14 & & \\
\hline & $(0.26)$ & $(0.14)$ & & \\
\hline \multirow{2}{*}{ Non-labour income } & $-0.12^{* *}$ & $-0.04 * *$ & & \\
\hline & $(0.01)$ & $(0.01)$ & & \\
\hline \multirow[t]{2}{*}{ Rural } & -0.17 & $-0.25^{* *}$ & & \\
\hline & $(0.25)$ & $(0.13)$ & & \\
\hline \multirow[t]{2}{*}{ Unemployment rate } & -0.06 & -0.03 & & \\
\hline & $(0.05)$ & $(0.02)$ & & \\
\hline \multirow[t]{2}{*}{ Low-skill } & $0.42^{*}$ & $0.73^{* *}$ & $0.13^{* *}$ & $0.09^{* *}$ \\
\hline & $(0.25)$ & $(0.14)$ & $(0.02)$ & $(0.04)$ \\
\hline \multirow[t]{2}{*}{ Intermed.-skill } & $0.56^{* *}$ & $0.95^{* *}$ & $0.37^{* *}$ & $0.32^{* *}$ \\
\hline & $(0.28)$ & $(0.20)$ & $(0.03)$ & $(0.05)$ \\
\hline \multirow[t]{2}{*}{ High-skill } & $1.03^{* *}$ & $1.41^{* *}$ & $0.76^{* *}$ & $0.65^{* *}$ \\
\hline & $(0.53)$ & $(0.34)$ & $(0.03)$ & $(0.06)$ \\
\hline
\end{tabular}


Table 9. Estimates of the covariance matrix: standard deviations and correlation coefficients Only weekday diaries, $N=1080$

\begin{tabular}{|c|c|c|c|c|c|c|c|c|c|c|}
\hline & $\begin{array}{l}\text { Paid } \\
\text { work } \\
\text { husb. }\end{array}$ & $\begin{array}{l}\text { House } \\
\text { work } \\
\text { husb. }\end{array}$ & $\begin{array}{l}\text { Child } \\
\text { time } \\
\text { husb. }\end{array}$ & $\begin{array}{l}\text { Paid } \\
\text { work } \\
\text { wife }\end{array}$ & $\begin{array}{l}\text { House } \\
\text { work } \\
\text { wife }\end{array}$ & $\begin{array}{l}\text { Child } \\
\text { time } \\
\text { wife }\end{array}$ & $\begin{array}{l}\text { Empl. } \\
\text { men }\end{array}$ & $\begin{array}{l}\text { Empl. } \\
\text { wom. }\end{array}$ & $\begin{array}{l}\text { Wage } \\
\text { rate } \\
\text { husb. }\end{array}$ & $\begin{array}{l}\text { Wage } \\
\text { rate } \\
\text { wife }\end{array}$ \\
\hline Paid wk husb. & $4.42^{* *}$ & & & & & & & & & \\
\hline House wk husb. & $-0.50 * *$ & $1.66^{* *}$ & & & & & & & & \\
\hline Child tm husb. & $-0.20^{* *}$ & $0.20^{* *}$ & $1.39^{* *}$ & & & & & & & \\
\hline Paid wk wife & $0.18^{* *}$ & 0.01 & $0.16^{* *}$ & $5.94^{* *}$ & & & & & & \\
\hline House wk wife & $-0.09 * *$ & 0.00 & $-0.09 * *$ & $-0.75 * *$ & $2.15^{* *}$ & & & & & \\
\hline Child tm wife. & $0.09^{* *}$ & -0.05 & $0.13^{* *}$ & $-0.38 * *$ & $0.18^{* *}$ & $1.62^{* *}$ & & & & \\
\hline Empl. husb. & $0.69 * *$ & $-0.18^{* *}$ & $-0.16^{*}$ & $0.17^{*}$ & -0.10 & 0.05 & 1.00 & & & \\
\hline Empl. wife & 0.07 & $0.14^{* *}$ & 0.07 & $0.83^{* *}$ & $-0.53^{* *}$ & $-0.29 * *$ & $0.24^{* *}$ & 1.00 & & \\
\hline Wage rt husb. & $-0.18^{* *}$ & $0.15^{* *}$ & 0.08 & -0.07 & $0.10^{* *}$ & 0.03 & 0.02 & -0.06 & $0.24^{* *}$ & \\
\hline Wage rt wife & -0.05 & -0.02 & $-0.10^{*}$ & $-0.32 * *$ & $0.33^{* *}$ & 0.10 & -0.03 & 0.00 & $0.26^{* *}$ & $0.24^{* *}$ \\
\hline
\end{tabular}

Table 10: Elasticities

\begin{tabular}{lrrr}
\hline Elasticity of: & $\begin{array}{r}\text { Wage } \\
\text { husband }\end{array}$ & $\begin{array}{r}\text { Wage } \\
\text { wife }\end{array}$ & $\begin{array}{r}\text { Non-labour } \\
\text { income }\end{array}$ \\
\hline Paid work: & $0.41^{* *}$ & -0.01 & $-0.10^{* *}$ \\
Paid work husband & $(0.14)$ & $(0.09)$ & $(0.02)$ \\
& -0.07 & $1.40^{* *}$ & $-0.08^{* *}$ \\
Paid work wife & $(0.12)$ & $(0.30)$ & $(0.02)$ \\
& $0.25^{* *}$ & $0.47^{* *}$ & $-0.10^{* *}$ \\
Total paid work time, for both spouses & $(0.10)$ & $(0.14)$ & $(0.01)$ \\
& & & \\
Housework time: & $-0.56^{* *}$ & $0.49^{* *}$ & $0.08^{* *}$ \\
Housework husband & $(0.27)$ & $(0.16)$ & $(0.04)$ \\
& -0.09 & $-0.74^{* *}$ & 0.01 \\
Housework wife & $(0.06)$ & $(0.16)$ & $(0.01)$ \\
Total housework time, for both spouses & $-0.18^{* *}$ & $-0.51^{* *}$ & $0.03^{*}$ \\
& $(0.07)$ & $(0.13)$ & $(0.01)$ \\
Childcare time: & & & \\
Childcare time husband & -0.52 & $0.57^{* *}$ & $0.08^{*}$ \\
Childcare time wife & $(0.34)$ & $(0.21)$ & $(0.05)$ \\
& -0.07 & -0.31 & $0.04^{* *}$ \\
Total childcare time, for both spouses & $(0.10)$ & $(0.21)$ & $(0.02)$ \\
& -0.17 & -0.11 & $0.05^{* *}$ \\
& $(0.12)$ & $(0.18)$ & $(0.02)$ \\
\hline
\end{tabular}


Table 11: Estimates of the time-use equations

Only weekday diaries, $N=1080$, other definition of housework

\begin{tabular}{|c|c|c|c|c|c|c|}
\hline & & Husbands & & & Wives & \\
\hline Variable & Paid & Housewk & Child & Paid & Housewk & Child \\
\hline Log wage rate & $2.86^{* *}$ & $-1.93^{* *}$ & $-0.65^{*}$ & $-1.13^{* *}$ & -0.03 & -0.06 \\
\hline husband & $(1.02)$ & $(0.60)$ & $(0.38)$ & $(0.69)$ & $(0.26)$ & $(0.22)$ \\
\hline Log wage rate & -0.03 & 0.52 & $0.61^{* *}$ & $7.67^{* *}$ & $-3.20^{* *}$ & -0.64 \\
\hline wife & $(0.68)$ & $(0.40)$ & $(0.23)$ & $(2.02)$ & $(0.72)$ & $(0.47)$ \\
\hline Intercept & -70.97 & -18.16 & $-43.24^{* *}$ & $-155.34^{* *}$ & 27.55 & $-50.09 * *$ \\
\hline & $(43.45)$ & $(27.96)$ & $(15.92)$ & $(36.42)$ & $(17.81)$ & (12.15) \\
\hline Log age & 37.94 & 11.26 & $24.71^{* *}$ & $76.67^{* *}$ & -10.26 & $32.65^{* *}$ \\
\hline & $(23.92)$ & $(15.27)$ & $(8.80)$ & $(20.15)$ & $(9.83)$ & $(6.91)$ \\
\hline Log age squared & $-5.55^{*}$ & -1.23 & $-3.58^{* *}$ & -10.91 & 1.91 & $-5.04^{* *}$ \\
\hline & $(3.25)$ & $(2.07)$ & $(1.20)$ & $(2.81)$ & $(1.36)$ & $(0.97)$ \\
\hline Compulsory Ed. & -0.73 & 0.53 & $0.55^{* *}$ & 1.07 & -0.05 & 0.02 \\
\hline & $(0.72)$ & $(0.42)$ & $(0.25)$ & $(0.85)$ & $(0.32)$ & $(0.25)$ \\
\hline Low secondary & -0.01 & $0.53^{* *}$ & $0.40^{* *}$ & -0.24 & 0.19 & $0.42^{* *}$ \\
\hline & $(0.44)$ & $(0.27)$ & $(0.16)$ & $(0.78)$ & $(0.30)$ & $(0.20)$ \\
\hline Upper secondary & -0.58 & 0.65 & $0.52^{* *}$ & -1.19 & 0.30 & $1.00 * *$ \\
\hline & $(0.73)$ & $(0.44)$ & $(0.25)$ & $(1.03)$ & $(0.41)$ & $(0.26)$ \\
\hline University, short & -0.61 & 0.70 & 0.51 & -0.69 & 0.73 & $0.69^{*}$ \\
\hline & $(0.89)$ & $(0.54)$ & $(0.32)$ & $(1.52)$ & $(0.57)$ & $(0.38)$ \\
\hline Univers. and higher & -0.84 & 0.88 & $1.07 * *$ & -2.72 & $1.44^{*}$ & $1.13^{* *}$ \\
\hline & $(1.08)$ & $(0.66)$ & $(0.37)$ & $(2.13)$ & $(0.79)$ & $(0.50)$ \\
\hline Married & 0.58 & 0.05 & -0.17 & -0.40 & $0.58^{* *}$ & -0.09 \\
\hline & $(0.41)$ & $(0.25)$ & $(0.17)$ & $(0.56)$ & $(0.24)$ & $(0.16)$ \\
\hline French national & $1.50^{* *}$ & 0.40 & 0.21 & $2.35^{* *}$ & -0.44 & 0.13 \\
\hline & $(0.63)$ & $(0.38)$ & $(0.25)$ & $(1.00)$ & $(0.34)$ & $(0.28)$ \\
\hline Children, age $<3$ & -0.05 & 0.08 & $0.63^{* *}$ & $-1.58^{* *}$ & -0.20 & $1.29 * *$ \\
\hline & $(0.45)$ & $(0.30)$ & $(0.16)$ & $(0.62)$ & $(0.26)$ & $(0.16)$ \\
\hline No. of children & 0.23 & -0.17 & 0.09 & $-1.53^{* *}$ & $0.34^{* *}$ & $0.52^{* *}$ \\
\hline & $(0.17)$ & $(0.11)$ & $(0.07)$ & $(0.26)$ & $(0.08)$ & $(0.06)$ \\
\hline Ile de France & 0.29 & $-0.61^{* *}$ & 0.16 & 0.51 & $-0.59^{* *}$ & 0.07 \\
\hline & $(0.47)$ & $(0.27)$ & $(0.15)$ & $(0.57)$ & $(0.22)$ & $(0.15)$ \\
\hline Non-labour income & $-0.24^{* *}$ & $0.06^{* *}$ & $0.03^{* *}$ & $-0.18^{* *}$ & 0.03 & $0.03^{* *}$ \\
\hline & $(0.04)$ & $(0.02)$ & $(0.01)$ & $(0.05)$ & $(0.02)$ & $(0.01)$ \\
\hline Rural & -0.27 & 0.13 & 0.04 & $-0.93^{*}$ & 0.15 & -0.01 \\
\hline & $(0.41)$ & $(0.25)$ & $(0.15)$ & $(0.54)$ & $(0.20)$ & $(0.15)$ \\
\hline
\end{tabular}


Table 12: Estimates of the employment and wage equations Only weekday diaries, $N=1080$, other definition of housework

\begin{tabular}{|c|c|c|c|c|}
\hline \multirow{2}{*}{ Variable } & \multicolumn{2}{|c|}{$\begin{array}{c}\text { Employment } \\
\text { equations }\end{array}$} & \multicolumn{2}{|c|}{$\begin{array}{c}\text { Wage } \\
\text { equations }\end{array}$} \\
\hline & Husbands & Wives & Husbands & Wives \\
\hline \multirow[t]{2}{*}{ Intercept } & -12.82 & $-34.89^{* *}$ & 0.66 & 2.39 \\
\hline & $(23.49)$ & $(8.24)$ & $(2.23)$ & $(2.43)$ \\
\hline \multirow[t]{2}{*}{ Log age } & 8.68 & $19.49^{* *}$ & 1.14 & 0.02 \\
\hline & $(12.81)$ & $(4.62)$ & $(1.22)$ & $(1.34)$ \\
\hline \multirow[t]{2}{*}{ Log age-squared } & -1.29 & $-2.68^{* *}$ & -0.09 & 0.07 \\
\hline & $(1.74)$ & $(0.64)$ & $(0.17)$ & $(0.18)$ \\
\hline \multirow[t]{2}{*}{ Compulsory Ed. } & 0.41 & $0.55^{* *}$ & $0.13^{* *}$ & $0.14^{* *}$ \\
\hline & $(0.43)$ & $(0.18)$ & $(0.03)$ & $(0.03)$ \\
\hline \multirow[t]{2}{*}{ Low secondary } & 0.26 & $0.30 * *$ & $0.11^{* *}$ & $0.20^{* *}$ \\
\hline & $(0.22)$ & $(0.14)$ & $(0.02)$ & $(0.03)$ \\
\hline \multirow[t]{2}{*}{ Upper secondary } & $0.72^{*}$ & 0.23 & $0.13^{* *}$ & $0.29 * *$ \\
\hline & $(0.37)$ & $(0.17)$ & $(0.03)$ & $(0.03)$ \\
\hline \multirow[t]{2}{*}{ University, short } & 0.38 & 0.33 & $0.25^{* *}$ & $0.44^{* *}$ \\
\hline & $(0.41)$ & $(0.22)$ & $(0.03)$ & $(0.04)$ \\
\hline \multirow[t]{2}{*}{ Univers. and higher } & 0.58 & 0.23 & $0.34^{* *}$ & $0.58^{* *}$ \\
\hline & $(0.48)$ & $(0.30)$ & $(0.03)$ & $(0.04)$ \\
\hline \multirow[t]{2}{*}{ Married } & 0.15 & 0.03 & & \\
\hline & $(0.23)$ & $(0.14)$ & & \\
\hline \multirow[t]{2}{*}{ French nationality } & 0.36 & $0.48^{* *}$ & & \\
\hline & $(0.29)$ & $(0.22)$ & & \\
\hline \multirow[t]{2}{*}{ Children, age $<3$} & -0.32 & $-0.29 *$ & & \\
\hline & $(0.23)$ & $(0.15)$ & & \\
\hline \multirow[t]{2}{*}{ No. of children } & 0.11 & $-0.39^{* *}$ & & \\
\hline & $(0.08)$ & $(0.06)$ & & \\
\hline \multirow[t]{2}{*}{ Ile de France } & -0.10 & 0.12 & & \\
\hline & $(0.26)$ & $(0.14)$ & & \\
\hline \multirow[t]{2}{*}{ Non-labour income } & $-0.12^{* *}$ & $-0.04^{* *}$ & & \\
\hline & $(0.01)$ & $(0.01)$ & & \\
\hline \multirow[t]{2}{*}{ Rural } & -0.17 & $-0.23^{*}$ & & \\
\hline & $(0.25)$ & $(0.12)$ & & \\
\hline \multirow[t]{2}{*}{ Unemployment rate } & -0.06 & $-0.04^{* *}$ & & \\
\hline & $(0.05)$ & $(0.02)$ & & \\
\hline \multirow[t]{2}{*}{ Low-skill } & $0.40^{*}$ & $0.75^{* *}$ & $0.13^{* *}$ & $0.09^{* *}$ \\
\hline & $(0.24)$ & $(0.14)$ & $(0.02)$ & $(0.04)$ \\
\hline \multirow[t]{2}{*}{ Intermed.-skill } & $0.58^{* *}$ & $0.98^{* *}$ & $0.37^{* *}$ & $0.33^{* *}$ \\
\hline & $(0.28)$ & $(0.20)$ & $(0.03)$ & $(0.05)$ \\
\hline \multirow[t]{2}{*}{ High-skill } & $0.98^{*}$ & $1.40^{* *}$ & $0.75^{* *}$ & $0.65^{* *}$ \\
\hline & $(0.54)$ & $(0.33)$ & $(0.03)$ & $(0.06)$ \\
\hline
\end{tabular}


Table 13. Estimates of the covariance matrix: standard deviations and correlation coefficients Only weekday diaries, $N=1080$, other definition of housework

\begin{tabular}{|c|c|c|c|c|c|c|c|c|c|c|}
\hline & $\begin{array}{l}\text { Paid } \\
\text { work } \\
\text { husb. }\end{array}$ & $\begin{array}{l}\text { House } \\
\text { work } \\
\text { husb. }\end{array}$ & $\begin{array}{l}\text { Child } \\
\text { time } \\
\text { husb. }\end{array}$ & $\begin{array}{l}\text { Paid } \\
\text { work } \\
\text { wife }\end{array}$ & $\begin{array}{l}\text { House } \\
\text { work } \\
\text { wife }\end{array}$ & $\begin{array}{l}\text { Child } \\
\text { time } \\
\text { wife }\end{array}$ & $\begin{array}{l}\text { Empl. } \\
\text { men }\end{array}$ & $\begin{array}{l}\text { Empl. } \\
\text { wom. }\end{array}$ & $\begin{array}{l}\text { Wage } \\
\text { rate } \\
\text { husb. }\end{array}$ & $\begin{array}{l}\text { Wage } \\
\text { rate } \\
\text { wife }\end{array}$ \\
\hline Paid wk husb. & $4.45^{* *}$ & & & & & & & & & \\
\hline House wk husb. & $-0.66^{* *}$ & $2.61^{* *}$ & & & & & & & & \\
\hline Child tm husb. & $-0.20 * *$ & $0.10^{* *}$ & $1.38^{* *}$ & & & & & & & \\
\hline Paid wk wife & $0.18^{* *}$ & $-0.07^{*}$ & $0.16^{* *}$ & $5.86^{* *}$ & & & & & & \\
\hline House wk wife & $-0.10^{* *}$ & $0.11^{* *}$ & $-0.11^{* *}$ & $-0.77^{* *}$ & $2.34^{* *}$ & & & & & \\
\hline Child tm wife. & $0.10^{* *}$ & $-0.09 * *$ & $0.12^{* *}$ & $-0.37^{* *}$ & $0.15^{* *}$ & $1.61^{* *}$ & & & & \\
\hline Empl. husb. & $0.68^{* *}$ & $-0.25^{* *}$ & $-0.15^{*}$ & $0.18^{* *}$ & -0.14 & 0.06 & 1.00 & & & \\
\hline Empl. wife & 0.07 & 0.05 & 0.09 & $0.83^{* *}$ & $-0.57^{* *}$ & $-0.28^{* *}$ & 0.24 & 1.00 & & \\
\hline Wage rt husb. & $-0.17 * *$ & $0.20 * *$ & 0.08 & -0.06 & $0.09 * *$ & 0.03 & 0.02 & -0.05 & $0.24^{* *}$ & \\
\hline Wage rt wife & -0.05 & 0.05 & $-0.10^{*}$ & $-0.31^{* *}$ & $0.32^{* *}$ & 0.10 & -0.04 & 0.01 & $0.26^{* *}$ & $0.24^{* *}$ \\
\hline
\end{tabular}

Table 14: Elasticities: Only weekday diaries, other definition of housework

\begin{tabular}{lrrr}
\hline Elasticity of: & $\begin{array}{r}\text { Wage } \\
\text { husband }\end{array}$ & $\begin{array}{r}\text { Wage } \\
\text { wife }\end{array}$ & $\begin{array}{r}\text { Non-labour } \\
\text { income }\end{array}$ \\
\hline Paid work: & $0.40^{* *}$ & -0.004 & $-0.10^{* *}$ \\
Paid work husband & $(0.14)$ & $(0.10)$ & $(0.02)$ \\
& -0.08 & $1.34^{* *}$ & $-0.08^{* *}$ \\
Paid work wife & $(0.13)$ & $(0.30)$ & $(0.03)$ \\
Total paid work time, for both spouses & $0.24^{* *}$ & $0.45^{* *}$ & $-0.10^{* *}$ \\
& $(0.11)$ & $(0.14)$ & $(0.02)$ \\
Housework time: & & & \\
Housework husband & $-0.68^{* *}$ & 0.19 & $0.08^{* *}$ \\
& $(0.21)$ & $(0.15)$ & $(0.04)$ \\
Housework wife & -0.08 & $-0.72^{* *}$ & 0.02 \\
& $(0.06)$ & $(0.16)$ & $(0.01)$ \\
Total housework time, for both spouses & $-0.27^{* *}$ & $-0.43^{* *}$ & $0.04^{* *}$ \\
& $(0.08)$ & $(0.12)$ & $(0.02)$ \\
Childcare time: & & & \\
Childcare time husband & -0.53 & $0.55^{* *}$ & 0.08 \\
Childcare time wife & $(0.33)$ & $(0.22)$ & $(0.06)$ \\
& -0.06 & -0.29 & $0.04^{* *}$ \\
Total childcare time, for both spouses & $(0.10)$ & $(0.21)$ & $(0.02)$ \\
& -0.17 & -0.10 & $0.05^{* *}$ \\
& $(0.11)$ & $(0.18)$ & $(0.02)$ \\
\hline
\end{tabular}


Table A: Elasticities: including weekend diaries

\begin{tabular}{lrrr}
\hline Elasticity of: & $\begin{array}{r}\text { Wage } \\
\text { husband }\end{array}$ & $\begin{array}{r}\text { Wage } \\
\text { wife }\end{array}$ & $\begin{array}{r}\text { Non-labour } \\
\text { income }\end{array}$ \\
\hline Paid work: & $0.34^{* *}$ & 0.10 & $-0.10^{* *}$ \\
Paid work husband & $(0.14)$ & $(0.09)$ & $(0.01)$ \\
& -0.05 & $1.21^{* *}$ & $-0.08^{* *}$ \\
Paid work wife & $(0.12)$ & $(0.28)$ & $(0.02)$ \\
Total paid work time, for both spouses & $0.21^{* *}$ & $0.47^{* *}$ & $-0.09^{* *}$ \\
& $(0.10)$ & $(0.12)$ & $(0.01)$ \\
Housework time: & & \\
Housework husband & $-0.42^{* *}$ & $0.42^{* *}$ & $0.07^{*}$ \\
& $(0.20)$ & $(0.12)$ & $(0.04)$ \\
Housework wife & $-0.14^{* *}$ & $-0.56^{* *}$ & 0.01 \\
& $(0.05)$ & $(0.12)$ & $(0.01)$ \\
Total housework time, for both spouses & $-0.20^{* *}$ & $-0.35^{* *}$ & $0.02^{*}$ \\
& $(0.06)$ & $(0.10)$ & $(0.01)$ \\
Childcare time: & & & \\
Childcare time husband & -0.34 & $0.58^{* *}$ & $0.07^{*}$ \\
& $(0.26)$ & $(0.20)$ & $(0.04)$ \\
Childcare time wife & -0.01 & -0.09 & $0.03^{*}$ \\
& $(0.09)$ & $(0.17)$ & $(0.02)$ \\
Total childcare time, for both spouses & -0.10 & 0.09 & $0.04^{* *}$ \\
& $(0.10)$ & $(0.14)$ & $(0.02)$ \\
\hline
\end{tabular}


Table B: Elasticities: other definition of housework, including weekend diaries

\begin{tabular}{lrrr}
\hline Elasticity of: & $\begin{array}{r}\text { Wage } \\
\text { husband }\end{array}$ & $\begin{array}{r}\text { Wage } \\
\text { wife }\end{array}$ & $\begin{array}{r}\text { Non-labour } \\
\text { income }\end{array}$ \\
\hline Paid work: & $0.31^{* *}$ & 0.10 & $-0.10^{* *}$ \\
Paid work husband & $(0.13)$ & $(0.09)$ & $(0.01)$ \\
& -0.06 & $1.15^{* *}$ & $-0.08^{* *}$ \\
Paid work wife & $(0.12)$ & $(0.28)$ & $(0.03)$ \\
& $0.19^{*}$ & $0.46^{* *}$ & $-0.09^{* *}$ \\
Total paid work time, for both spouses & $(0.10)$ & $(0.12)$ & $(0.01)$ \\
& & & \\
Housework time: & $-0.53^{* *}$ & 0.17 & $0.05^{* *}$ \\
Housework husband & $(0.16)$ & $(0.11)$ & $(0.02)$ \\
& $-0.12^{* *}$ & $-0.50^{* *}$ & 0.02 \\
Housework wife & $(0.05)$ & $(0.11)$ & $(0.01)$ \\
Total housework time, for both spouses & $-0.26^{* *}$ & $-0.28^{* *}$ & $0.03^{* *}$ \\
& $(0.07)$ & $(0.09)$ & $(0.01)$ \\
Childcare time: & & & \\
Childcare time husband & -0.31 & $0.56^{* *}$ & $0.07^{*}$ \\
Childcare time wife & $(0.27)$ & $(0.16)$ & $(0.04)$ \\
& -0.01 & -0.10 & $0.03^{*}$ \\
Total childcare time, for both spouses & $(0.09)$ & $(0.17)$ & $(0.02)$ \\
& -0.09 & 0.08 & $0.04^{* *}$ \\
& $(0.10)$ & $(0.14)$ & $(0.02)$ \\
\hline
\end{tabular}


Table C: Elasticities: dropping non-labour income from the model Week diaries only

\begin{tabular}{lrr}
\hline Elasticity of: & $\begin{array}{r}\text { Wage } \\
\text { husband }\end{array}$ & $\begin{array}{r}\text { Wage } \\
\text { wife }\end{array}$ \\
\hline Paid work: & $0.46^{* *}$ & -0.01 \\
Paid work husband & $(0.15)$ & $(0.10)$ \\
& -0.10 & $1.51^{* *}$ \\
Paid work wife & $(0.13)$ & $(0.32)$ \\
Total paid work time, for both spouses & $0.29^{* *}$ & $0.44^{* *}$ \\
& $(0.11)$ & $(0.15)$ \\
Housework time: & & \\
Housework husband & $-0.45^{*}$ & $0.38^{* *}$ \\
& $(0.24)$ & $(0.15)$ \\
Housework wife & -0.08 & $-0.69^{* *}$ \\
& $(0.06)$ & $(0.17)$ \\
Total housework time, for both spouses & $-0.17^{* *}$ & $-0.43^{* *}$ \\
& $(0.07)$ & $(0.13)$ \\
Childcare time: & & \\
Childcare time husband & -0.51 & $0.55^{* *}$ \\
Childcare time wife & $(0.35)$ & $(0.21)$ \\
& -0.07 & -0.31 \\
Total childcare time, for both spouses & $(0.10)$ & $(0.21)$ \\
& -0.18 & -0.10 \\
& $(0.12)$ & $(0.18)$ \\
\hline
\end{tabular}


Table D: Elasticities

Allowing for correlation between non-labour income and the errors of the system Week diaries only

\begin{tabular}{lrrr}
\hline Elasticity of: & $\begin{array}{r}\text { Wage } \\
\text { husband }\end{array}$ & $\begin{array}{r}\text { Wage } \\
\text { wife }\end{array}$ & $\begin{array}{r}\text { Non-labour } \\
\text { income }\end{array}$ \\
\hline Paid work: & $0.42^{* *}$ & -0.004 & $-0.10^{* *}$ \\
Paid work husband & $(0.14)$ & $(0.09)$ & $(0.02)$ \\
Paid work wife & -0.07 & $1.38^{* *}$ & $-0.11^{* *}$ \\
& $(0.13)$ & $(0.31)$ & $(0.03)$ \\
Total paid work time, for both spouses & $0.25^{* *}$ & $0.47^{* *}$ & $-0.10^{* *}$ \\
& $(0.10)$ & $(0.14)$ & $(0.01)$ \\
Housework time: & & & $0.08^{* *}$ \\
Housework husband & $-0.56^{* *}$ & $0.49^{* *}$ & $(0.03)$ \\
& $(0.27)$ & $(0.16)$ & 0.01 \\
Housework wife & -0.09 & $-0.75^{* *}$ & $(0.02)$ \\
Total housework time, for both spouses & $(0.06)$ & $(0.16)$ & $0.03^{*}$ \\
& $-0.18^{* *}$ & $-0.51^{* *}$ & $(0.01)$ \\
Childcare time: & $(0.07)$ & $(0.14)$ & 0.08 \\
Childcare time husband & & & $(0.06)$ \\
Childcare time wife & -0.52 & $0.57^{* *}$ & $0.04^{* *}$ \\
Total childcare time, for both spouses & $(0.34)$ & $(0.21)$ & $(0.02)$ \\
& -0.06 & -0.31 & $0.05^{* *}$ \\
& $(0.10)$ & $(0.21)$ & $(0.02)$ \\
\hline
\end{tabular}

